\title{
Prostaglandins in Cancer Cell Adhesion, Migration, and Invasion
}

\author{
David G. Menter ${ }^{1}$ and Raymond N. DuBois ${ }^{1,2}$ \\ ${ }^{1}$ Department of Cancer Biology, The University of Texas MD Anderson Cancer Center, Houston, TX 77030, USA \\ ${ }^{2}$ Department of GI Medical Oncology, The University of Texas MD Anderson Cancer Center, Houston, TX 77030, USA
}

Correspondence should be addressed to Raymond N. DuBois, rdubois@mdanderson.org

Received 19 August 2011; Accepted 8 October 2011

Academic Editor: Eok-Soo Oh

Copyright ( 2012 D. G. Menter and R. N. DuBois. This is an open access article distributed under the Creative Commons Attribution License, which permits unrestricted use, distribution, and reproduction in any medium, provided the original work is properly cited.

Prostaglandins exert a profound influence over the adhesive, migratory, and invasive behavior of cells during the development and progression of cancer. Cyclooxygenase-2 (COX-2) and microsomal prostaglandin $\mathrm{E}_{2}$ synthase-1 (mPGES-1) are upregulated in inflammation and cancer. This results in the production of prostaglandin $\mathrm{E}_{2}\left(\mathrm{PGE}_{2}\right)$, which binds to and activates $\mathrm{G}$-proteincoupled prostaglandin $\mathrm{E}_{1-4}$ receptors $\left(\mathrm{EP}_{1-4}\right)$. Selectively targeting the COX-2/mPGES-1/PGE $2 / \mathrm{EP}_{1-4}$ axis of the prostaglandin pathway can reduce the adhesion, migration, invasion, and angiogenesis. Once stimulated by prostaglandins, cadherin adhesive connections between epithelial or endothelial cells are lost. This enables cells to invade through the underlying basement membrane and extracellular matrix (ECM). Interactions with the ECM are mediated by cell surface integrins by "outside-in signaling" through Src and focal adhesion kinase (FAK) and/or "inside-out signaling" through talins and kindlins. Combining the use of COX-2/mPGES-1/PGE $2 / \mathrm{EP}_{1-4}$ axis-targeted molecules with those targeting cell surface adhesion receptors or their downstream signaling molecules may enhance cancer therapy.

\section{The Prostaglandin Pathway}

Prostaglandins (PGs) and other eicosanoids are bioactive lipids that impact normal development, tissue homeostasis, inflammation, and cancer progression [1]. Prostaglandins are derived from the 20-carbon chain fatty acid, arachidonic acid (AA) stored in the plasma membrane of cells $[2,3]$. As a storage mechanism, dietary AA is coupled to CoA molecules by acyl-coenzyme A (acyl-CoA) synthetases [4]. In turn, fatty acyltransferases utilize arachidonyl-CoA donor molecules to insert AA into membrane phospholipids [2, 3]. Membrane phospholipids generally retain AA until an appropriate stimulus catalyzes its release by phospholipase A2 [5-8] (Figure 1).

Once released, free AA serves a substrate for cyclooxygenases (COX) 1 or $2(\sim 72 \mathrm{kDa}$; Figure 1). Cyclooxygenases are mixed function oxidase enzymes that first peroxidate AA to form a hydroperoxy endoperoxide that links two oxygen molecules across carbons 9 and 11 , prostaglandin $\mathrm{G}_{2}$ $\left(\mathrm{PGG}_{2}\right)$. As the second coordinate enzymatic function, $\mathrm{COXs}$ reduce a hydroperoxy-group at carbon 15 of $\mathrm{PGG}_{2}$ to form prostaglandin $\mathrm{H}_{2}\left(\mathrm{PGH}_{2}\right)[9,10]$. As a rate-limiting product in this pathway, $\mathrm{PGH}_{2}$ serves as the substrate for a variety of PG synthases. These PG synthases include various isoforms of prostaglandin $\mathrm{D}_{2}\left(\mathrm{PGD}_{2}\right)$ synthases (PGDS) [11], prostaglandin $\mathrm{E}_{2}\left(\mathrm{PGE}_{2}\right)$ synthases (PGES) [12-16], and prostaglandin $\mathrm{F}_{2 \alpha}\left(\mathrm{PGF}_{2 \alpha}\right)$ synthase (PGFS) [17]. $\mathrm{PGH}_{2}$ can also be synthesized into prostacyclin $\left(\mathrm{PGI}_{2}\right)$ by its own separate synthase $[18,19]$ (PGIS) or thromboxane $A_{2}\left(\mathrm{TxA}_{2}\right)$ by its synthase (TXS) [20]. In the case of inflammatory and carcinogenic activity, increased expression of COX-2 and microsomal PGE synthase-1 (mPGES-1) both occur to amplify the accumulation of $\mathrm{PGE}_{2}$ in tumors [21-26]. Once synthesized, prostanoids are transported into the extracellular microenvironment by specific multidrug resistance associated proteins (MRPs). These MRP molecules contain 12transmembrane spanning domains in the plasma membrane and two cytosolic ATP-binding/hydrolysis sites [27]. Among these export molecules, MRP4 is a $160 \mathrm{kDa}$ protein that acts as the primary transporter for PGs. Once exported to the microenvironment, prostanoids bind to G-protein coupled receptors that contain 7 transmembrane spanning domains. These PG receptors include DP1, DP2, EP1-4, FP, IP, and $\mathrm{TP}$ that are classified according to their ligand specificity 


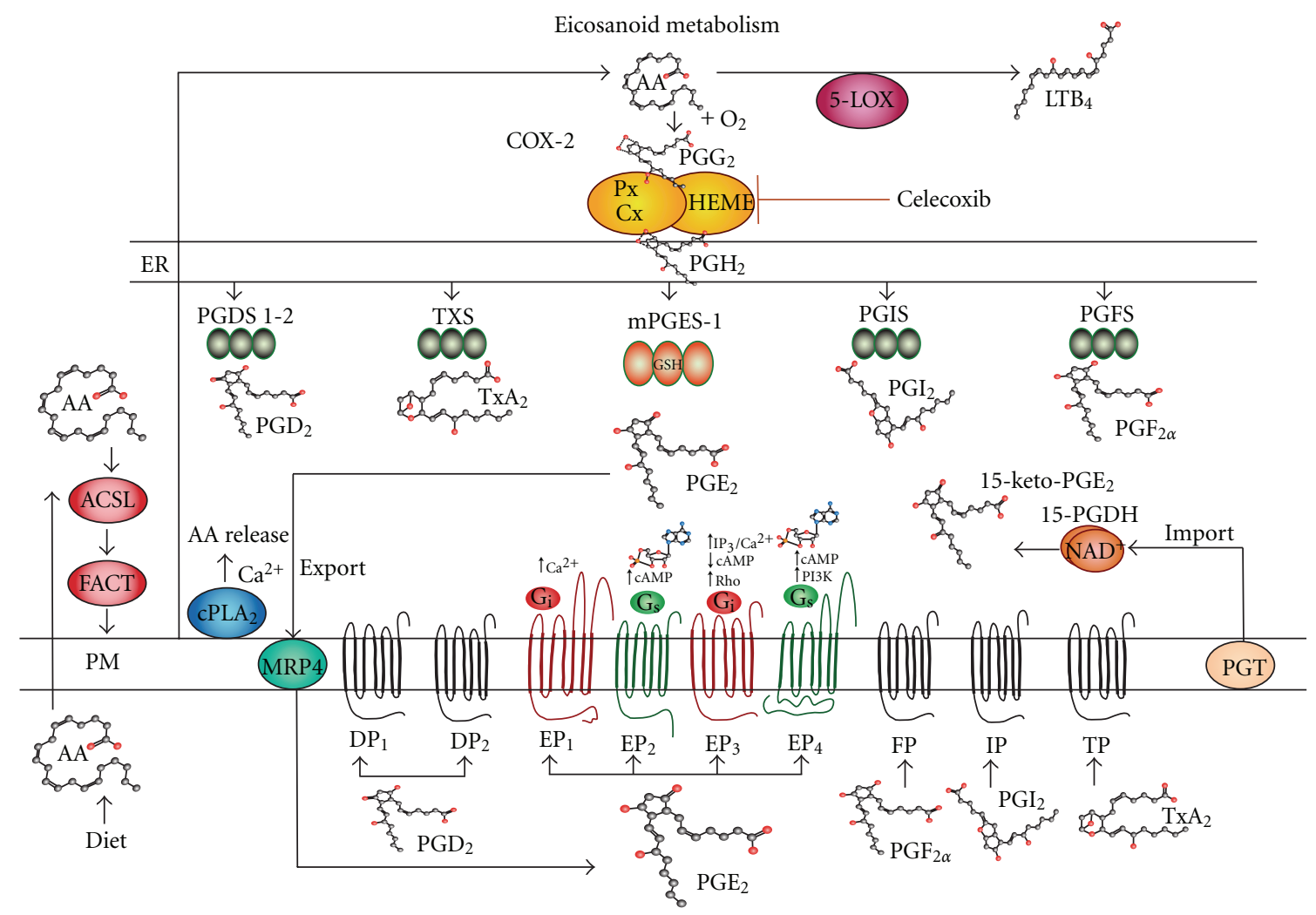

Figure 1: Eicosanoid metabolism. Arachidonic acid (AA) is an essential dietary fatty acid that is transported into cells and stored in membrane phospholipids. First AA is coupled to acyl-CoA by acyl-coenzyme A synthetases (ACLS). Fatty acyltransferases (FACT) then insert AA into membrane phospholipids. Cytoplasmic phospholipase A2 (cPLA2) releases AA from membrane phospholipids after agonist stimulation. In turn, free AA is converted to prostaglandin $\mathrm{G}_{2}\left(\mathrm{PGG}_{2}\right)$ and then prostaglandin $\mathrm{H}_{2}\left(\mathrm{PGH}_{2}\right)$ by cyclooxygenases $(\mathrm{COXs})$. $\mathrm{PGH}_{2}$ then becomes a substrate for a variety of PG synthases. These PG synthases are identified by the specific prostaglandin each one produces, namely, $\mathrm{PGD}_{2}$ synthases (PGDSs), $\mathrm{PGE}_{2}$ synthases (PGESs), $\left(\mathrm{PGF}_{2 \alpha}\right.$ ) synthase (PGFS), $\mathrm{PGI}_{2}$ synthase (PGIS), or TxA 2 synthase (TXS). Both COX-2 and microsomal PGE synthase-1 (mPGES-1) are elevated in tumors. Export involves multidrug resistance-associated protein 4 (MRP4). In the extracellular milieu, PGs bind to G-protein-coupled receptors identified as DP1, DP2, EP1-4, FP, IP, and TP. Among these, EP receptors interact with G-stimulatory (Gs) or G-inhibitory (Gi) proteins stimulating downstream signals such as cAMP, $\mathrm{Ca}^{2+}$, inositol phosphates or IP3/Ca ${ }^{2+}$, and Rho. Catabolism involves uptake by PG transporter (PGT) and inactivation by NAD + dependent 15-hydroxyprostaglandin dehydrogenase (15-PGDH).

[28]. There are four EP receptors that require G-stimulatory (Gs) or G-inhibitory (Gi) proteins to initiate downstream signals such as cAMP, $\mathrm{Ca}^{2+}$, and inositol phosphates [29]. More specifically, EP1 regulates $\mathrm{Ca}^{2+}$ flux; EP2 and EP4 both increase cAMP levels; whereas EP3 decreases cAMP, increases IP3/Ca ${ }^{2+}$, and activates Rho. These signaling pathways frequently initiate transcription or crosstalk with other signal transduction pathways [30-32]. Prostaglandins can also interact with nuclear receptors. Peroxisome proliferatoractivated receptors (PPARs) are nuclear receptors that also bind PGs and complex with retinoic X receptors (RXRs) to initiate gene transcription $[33,34]$. The catabolism of PG occurs as a two-step uptake and then inactivation process. PGs are taken up by a 12 transmembrane domain glycoprotein known as a PG transporter (PGT) [35-37]. After $\mathrm{PGE}_{2}$ is transported across the plasma membrane, it is enzymatically catabolized by NAD+ dependent 15-hydroxyprostaglandin dehydrogenase (15-PGDH) causing inactivation $[36,38,39]$. Two NAD+-15-PGDH protein monomers $(29 \mathrm{kDa})$ form enzymatically active complexes by dimerization. Interactions with biologically active prostaglandins containing hydroxyl groups at carbon 15 are inactivated by conversion to 15keto catabolites. The levels of both PGT and 15-PGDH are decreased in cancer leading to the accumulation of $\mathrm{PGE}_{2}$ in tumor tissues $[35,36,39,40]$. The accumulation of $\mathrm{PGE}_{2}$ in the developing tumor microenvironment promotes tissue reorganization, angiogenesis, as well as cell adhesion, migration and invasion through the basement membrane barrier.

\section{Prostaglandins and Cadherins: Making and Breaking Cell-Cell Contacts}

Prostaglandins play an important role in wound healing and tissue reorganization [41-46]. The ordered structure of epithelial and endothelial tissues involves the cadherin family of molecules [47-51]. In many epithelial and vascular tissues, prostaglandins influence the formation and loss of 
cell-cell contacts [52-56]. In vascular tissues for example, prostaglandins potentiate vascular endothelial VE-cadherindependent cell adhesion [57]. In the case of epithelial tissues, epithelial E-cadherins are structurally organized into adherens junctions that form extracellular $\mathrm{Ca}^{2+}$-dependent transmembrane adhesion complexes between adjacent cells (Figure 2).

In the cytoplasm of epithelial cells, binding proteins mediate interactions between the E-cadherin cytoplasmic domain and the actin cytoskeleton that can trigger a variety of signaling processes [51, 58-60]. Dynamic analyses have revealed that $\alpha$-catenin shuttles between cytoplasmic multiprotein complexes of $\beta$-catenin/E-cadherin or actin filaments [61]. $\beta$-catenin/E-cadherin interactions are regulated by IQGAPs that are actin-binding scaffold proteins [56-58]. IQGAPs interact with Rho GTPases and transmit extracellular signals that influence morphological and migratory cell behavior [62-64]. Alternate interactions through $\delta$-catenin involve p190 and RhoA [65]. Additional adherens junctions stabilization pathways also exist. One of these pathways includes the involvement of Src and p140Cap. p140Cap regulates Src activation by C-terminal Src kinase (Csk) activity in epithelial-rich tissues that is phosphorylated after cell matrix adhesion [66-68]. Similarly, receptor protein tyrosine phosphatase mu $(\mathrm{PTP} \mu)$ has a cell-adhesion molecule-like extracellular segment and a catalytically active intracellular segment involved in regulating cell-cell interactions $[69,70]$. Nectins-afadin complexes also regulate cell-cell adhesion cooperatively with cadherins and integrins $[71,72]$. Dynamic maintenance of cell-cell junctions in epithelial and endothelial tissues is critical to their functions as permeability or protective barriers and their continuous turnover as stress interfaces with the surrounding micro- or macro environment.

In order for epithelial cells to migrate, they must break their adhesive contacts with neighboring cells $[56,73]$. The disassembly of cadherin containing adherens junctions involves internalization through endocytosis that result in the formation of phagosomes [51]. Internalization occurs by either caveolin-mediated endocytosis or clathrin-mediated coated pits [74-76]. Once cadherin-containing phagosomes are internalized, the extracellular domain resides inside the vesicles that form. At the same time, $\beta$-catenin and Src that are bound to the cytoplasmic domain of E-cadherin at the plasma membrane end up on the outside of these vesicles. Interactions of these vesicles with Ras-related protein A (RalA) drive cadherin recycling [77]. Interactions between E-cadherin with Ras-proximate-1/Ras-related protein 1 (Rap1)-GTPase, E3 ubiquitin ligase followed by ubiquitinization lead to proteosomal degradation [78-80]. Thus, the internalization and turnover of E-cadherin enables cells preparing to migrate with the ability to break their adhesive contacts between adjacent cells.

Breaking adhesive contacts occurs during tissue homeostasis, angiogenesis, and cancer progression in vascular or epithelial tissues and is a very rapid process based on live cell imaging $[49,81,82]$. In the case of epithelial tissues, their normal uniform structure typically becomes disorganized or dysplastic and then anaplastic during cancer progression.
Disorganization in these tissues typically requires breaking cell-cell junctions maintained by cadherins such as E-cadherin [83]. In some cases this is mediated by prostaglandins. In squamous cell carcinoma, for example, chronically UVirradiated SKH-1 mice sequentially lose E-cadherin-mediated cell-cell contacts as lesions progress from dysplasia to SCCs [53] (see Table 1). In these studies, the loss of E-cadherin levels was inversely associated with increased $\mathrm{PGE}_{2}$ synthesis. Furthermore, the loss of E-cadherin involved the EP2 receptor and was reversed by indomethacin or potentiated by the EP2 receptor agonist butaprost [53].

Other epithelial tumors exhibit a similar loss of Ecadherin as COX-2/PGE 2 levels increase $[84,85]$. This loss of E-cadherin is often accompanied by an elevation of vimentin that is a characteristic of cells becoming more migratory during epithelial-to-mesenchymal transition (EMT) [86]. This EMT involving COX-2 is observed in human colon cancers [87]. The loss of E-cadherin in conjunction with elevations in COX-2 occurs during the transformation of rat intestinal epithelial (RIE) cells [88] and during adenoma formation in $\mathrm{Apc}^{\mathrm{Min} \backslash+}$ that exhibit aberrant $\beta$-catenin signaling [89] or during gastrulation involving the Snail pathway in Zebra fish [90]. The COX-2 promoter contains a novel functional T-cell factor/lymphoid enhancer factor (TCF/LEF) response element that responds directly to $\mathrm{Wnt} / \beta$-catenin signaling [91]. Regulation involving these pathways in some cases may be reversed. For example, caveolin-1-mediated suppression of COX-2 can occur via a $\beta$-catenin-Tcf/Lef-dependent transcriptional mechanism [92]. Overall, it is becoming clear that tissue homeostasis, reorganization, angiogenesis, and malignant transformation rely on very rapid dynamic making or breaking of cell-cell junctions centered on cadherin family of molecules. In most cases, epithelial tissues are strengthened by the synthesis and deposition of a basement membrane.

\section{The Basement Membrane Barrier}

Malignancies frequently develop from epithelial precancerous lesions that are initially confined to organ ducts or the epithelial strata of tissues. The pathologic conversion to cancerous lesions often involves malignant cells breaching or invading through the fibrous sheet-like barrier of the basement membrane (Figure 3) [93]. Prostaglandins are involved in the synthesis, homeostasis, turnover, and structural reorganization of the basement membrane [94, 95]. The basement membrane underlies the typical cellular epithelium or vascular endothelium and consists of two thin structural layers. The first layer consists of a basal lamina that is synthesized by epithelial or endothelial cells that differ in their respective characteristics [96]. The second layer is the reticular lamina made by fibroblasts, among other surrounding cells [97]. At the electron microscope level, the basal lamina is subdivided into a clear lamina lucida directly under the epithelial cells and a structurally opaque lamina densa [98, 99]. The lamina lucida contains protein and carbohydrate complexes at the cellular interface consisting of integrins, laminins (5, 6 and 10), and collagen XVII, as well as type IV collagen, laminin 1, and dystroglycans [97, 100, 101]. The lamina densa is a meshwork of type IV collagen fibers, 
Adherens junctions

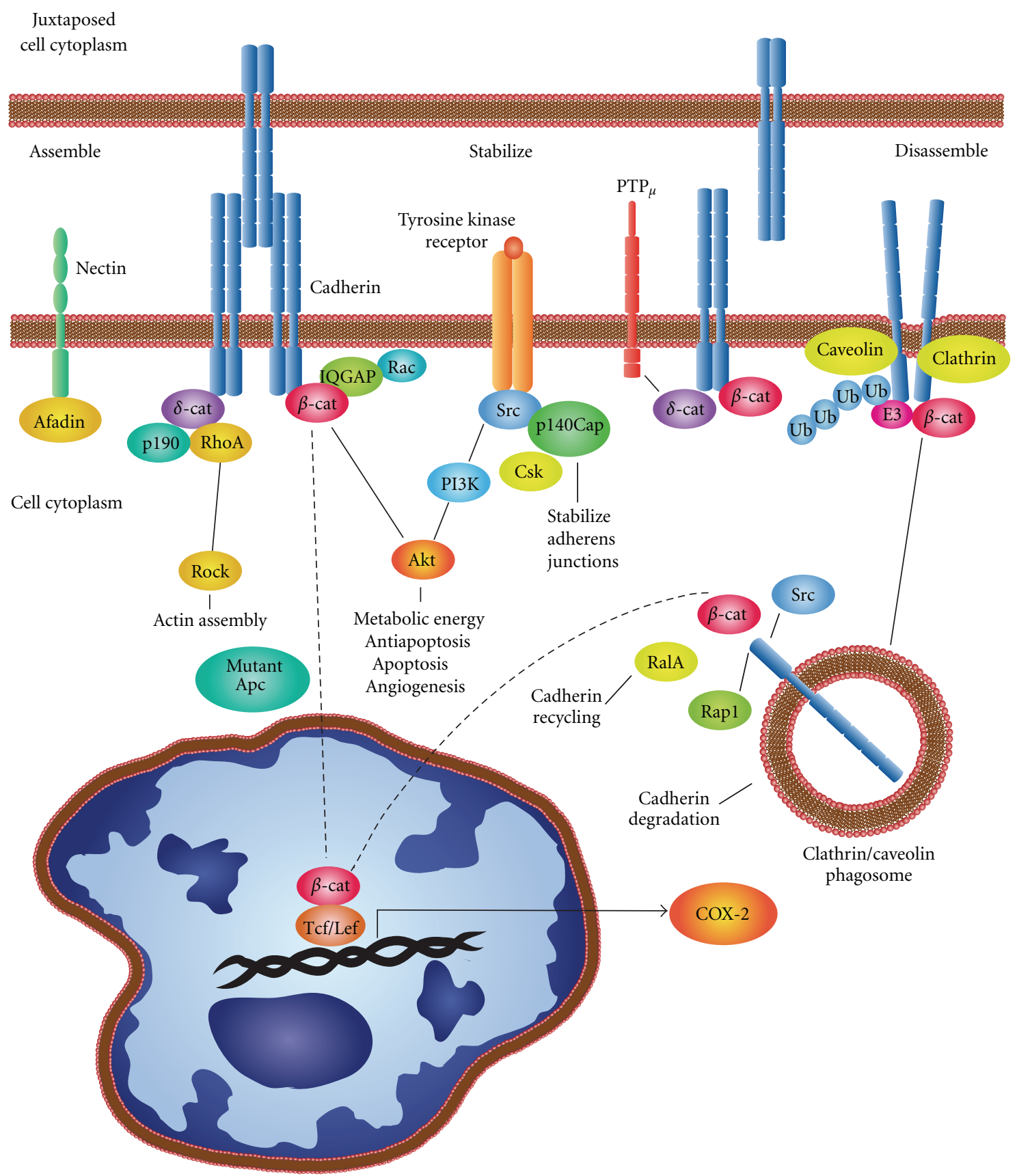

Figure 2: Dynamic adherens junctions. Prostaglandins influence the assembly, stabilization, and disassembly of cell-cell junctions. Ecadherins form $\mathrm{Ca}^{2+}$-dependent transmembrane adhesion complexes between adjacent cells (Figure 2). Cytoplasmic regulatory proteins include $\alpha$-catenin, $\beta$-catenin, IQGAPs scaffold proteins that interact with Rho GTPases to alter morphology and migration. Alternate interactions involve $\delta$-catenin, p190, and RhoA influencing actin assembly. Together, Src and p140Cap influence C-terminal Src kinase (Csk) activity stabilizing cell-cell interactions as well as similar activity by receptor protein tyrosine phosphatase mu (PTP $\mu$ ). Nectinsafadin complexes also cooperate with cadherins and integrins to regulate cell-cell adhesion. Disassembly of cadherin complexes involves either caveolin- or clathrin-mediated endocytosis and phagosome formation. Inside-out vesicles contain cadherin on the inside and $\beta$ catenin and Src exposed to the cytoplasm. When these vesicles interact with Ras-related protein A (RalA), cadherins are recycled. Whereas, interactions with Ras-proximate-1/Ras-related protein-1-(Rap1-)GTPase and E3 ubiquitin ligase followed by ubiquitinization result in proteosomal degradation that prepares cells for migration. The loss of E-cadherin in conjunction with elevations in COX-2 occurs during the transformation and adenoma formation in the presence of Apc mutations causing aberrant $\beta$-catenin signaling. Subsequent interactions with T-cell factor/lymphoid-enhancer-factor-(TCF/LEF-) can cause increases in COX-2 expression. 
TABLE 1: Prostaglandins in cancer cell adhesion, migration, and invasion summary table.

\begin{tabular}{|c|c|c|c|c|}
\hline Adhesive factor & Tissue & PG & Biological effect & Refs \\
\hline \multicolumn{5}{|l|}{ Cadherins } \\
\hline$\downarrow$ E-cadherin & RIE-S & $\uparrow \mathrm{PGE}_{2}$ & $\begin{array}{l}\mathrm{COX}-2 \text {-mediated } \mathrm{PGE}_{2} \text { production in rat intestinal epithelial cells (RIE) } \\
\text { downregulates E-cadherin }\end{array}$ & {$[88]$} \\
\hline$\downarrow$ E-cadherin & SCC & $\uparrow \mathrm{PGE}_{2}$ & $\begin{array}{l}\text { Downregulates E-cadherin through the EP2 receptor during squamous cell } \\
\text { carcinoma (SCC) progression }\end{array}$ & {$[53]$} \\
\hline$\uparrow$ E-cadherin & NSCLC & $\downarrow \mathrm{PGE}_{2}$ & $\begin{array}{l}\text { S-valproate and S-diclofenac increased E-cadherin but reduced vimentin and } \\
\text { ZEB1 }\end{array}$ & {$[84]$} \\
\hline$\downarrow$ E-cadherin & TCC & $\uparrow \mathrm{PGE}_{2}$ & $\begin{array}{l}\text { Reciprocal correlation between cyclooxygenase-2 expression and E-cadherin } \\
\text { in human bladder transitional cell carcinoma (TCC). }\end{array}$ & {$[85,87]$} \\
\hline$\uparrow$ E-cadherin & Melanoma & $\uparrow \mathrm{PGE}_{2}$ & $\begin{array}{l}\text { Decrease of TGF } \beta 1 \text {-induced EMT properties in Madin-Darby canine kidney } \\
\text { (MDCK) cells is associated with regaining E-cadherin expression }\end{array}$ & {$[257]$} \\
\hline$\uparrow$ E-cadherin & MDCK & $\uparrow \mathrm{PGD}_{2}$ & $\begin{array}{l}\text { Decrease of TGF } \beta 1 \text {-induced EMT properties in MDCK cells is associated with } \\
\text { regaining E-cadherin expression }\end{array}$ & {$[258]$} \\
\hline$\downarrow$ VE-cadherin & HLVE & $\downarrow \mathrm{PGI}_{2}$ & $\begin{array}{l}\text { Inhibition of } \mathrm{PGI}_{2} \text {-mediated human lung vascular endothelial cell (HLVE) } \\
\text { responses decreased VE-cadherin expression and increased eosinophil } \\
\text { adhesion }\end{array}$ & {$[259]$} \\
\hline \multicolumn{5}{|c|}{ 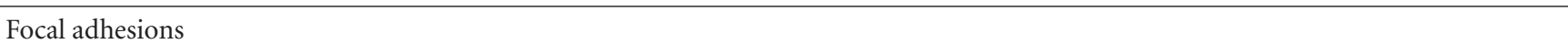 } \\
\hline$\uparrow$ Actin bundles & $\mathrm{HeLa}$ & $\uparrow \mathrm{PGE}_{2}$ & Examination of cyclooxygenase-dependent actin bundles in HeLa cells. & {$[144]$} \\
\hline CREB activation & Raw264.7 & $\uparrow \mathrm{COX} 2$ & $\begin{array}{l}\text { Examination of Col-I on the COX- } 2 \text { expression and the signaling pathways in } \\
\text { macrophages. }\end{array}$ & {$[145]$} \\
\hline $\begin{array}{l}\uparrow \text { Focal } \\
\text { adhesions }\end{array}$ & Osteoblasts & $\uparrow \mathrm{COX} 2$ & $\begin{array}{l}\text { Focal adhesion promotes fluid shear stress induction of COX-2 and } \mathrm{PGE}_{2} \\
\text { release in osteoblasts }\end{array}$ & $\begin{array}{c}{[146-} \\
148]\end{array}$ \\
\hline $\begin{array}{l}\uparrow \text { Focal } \\
\text { adhesions }\end{array}$ & 293-EBNA-HEK & $\uparrow \mathrm{PGF} 2 \alpha$ & Regulates Rho-mediated morphological changes & $\begin{array}{l}{[150,} \\
151]\end{array}$ \\
\hline \multicolumn{5}{|l|}{ Integrins } \\
\hline$\alpha_{2} \beta_{1}$ & Caco-2 & $\uparrow \mathrm{LTD}_{4} / \uparrow \mathrm{PGE}_{2}$ & Increased adhesion to collagen I. & {$[177]$} \\
\hline$\beta_{1}$ & HT-29 & $\downarrow \mathrm{PGE}_{2}$ & Decreased adhesion and migration on extracellular matrix & {$[178]$} \\
\hline$\alpha_{3}$ & Mammary TC & $\downarrow \mathrm{PGE}_{2}$ & Decreased adhesion to laminin & {$[179]$} \\
\hline$\alpha_{5} \beta_{1}$ & HLC & $\uparrow \mathrm{PGE}_{2}$ & Increased adhesion of human lung carcinoma (HLC) cells to fibronectin & {$[180]$} \\
\hline$\alpha \operatorname{IIb} \beta_{3}$ & B16a melanoma & $\uparrow 12$-HETE & $\begin{array}{l}\text { Increased adhesion to fibronectin, endothelial cells, and endothelial cell } \\
\text { matrix }\end{array}$ & $\begin{array}{c}{[182,} \\
183]\end{array}$ \\
\hline
\end{tabular}

entactin/nidogen-1, as well as perlecan, along with hydrous polysaccharide-rich gels of heparan sulfate proteoglycans. The reticular lamina contains collagens I, III, and V that form a heterogeneous network of fibers and a variety of proteoglycans [97]. Some basement membrane structures also contain pores that allow for the passage of cells [97]. The basement membrane is extensively remodeled during inflammatory responses $[102,103]$ or becomes disorganized in tumor vasculature [104] and in various cancers [105]. Thus there are a large variety of molecules encountered during invasion through the basement membrane that require the expression of many different cell surface adhesion receptors including integrins, cell surface proteoglycans, and tetraspanins.

\section{Integrins}

Mammalian integrins generate heterodimeric transmembrane glycoprotein adhesion receptor complexes consisting of $\alpha$ and $\beta$ subunits (Figure 4) [106-109]. Alpha-numeric designations are applied to 18 known $\alpha$ subunits ( $\alpha 1-$ $11, \mathrm{D}, \mathrm{E}, \mathrm{L}, \mathrm{M}, \mathrm{V}, \mathrm{W}, \mathrm{X})$ and $8 \beta$ subunits $(\beta 1-8)$ available to form pairs in this class of molecules. Each selective pairing recognizes a different ICAM, ligand, or protein substrate in the basement membrane or extracellular matrix $[110,111]$. The $\alpha$ subunit dictates the ligand specificity by virtue of a seven-bladed $\beta$-propeller head domain connected to a leg support structure made of a thigh, a calf-1, a calf-2, a transmembrane, and a cytoplasmic domain [107, 112]. The $\beta$ subunit interacts with the cell cytoskeleton and contains an N-terminal plexin-semaphorin-integrin (PSI) domain, a hybrid domain, a $\beta$ I domain, four cysteine-rich epidermal growth factor (EGF) repeats, a transmembrane, and a cytoplasmic domain $[107,112]$. In many cases, the $\mathrm{N}$-terminal $\beta$-I domain of a $\beta$ subunit inserts into the $\beta$ propeller domain of an $\alpha$ subunit $(\alpha 1, \alpha 2, \alpha 10, \alpha 11, \alpha \mathrm{L}, \alpha \mathrm{M}$, $\alpha \mathrm{X}$, and $\alpha \mathrm{D}$ ) to form a bulbous-binding headpiece complex [112]. The formation of integrin receptor complexes depends on divalent cation (i.e., $\mathrm{Ca}^{2+}, \mathrm{Mn}^{2+}, \mathrm{Mg}^{2+}$ ) that bind to metal-ion-dependent adhesion site (MIDAS) motifs in the $\alpha$ subunits and adjacent to MIDAS (ADMIDAS) motifs in 
Basement membrane

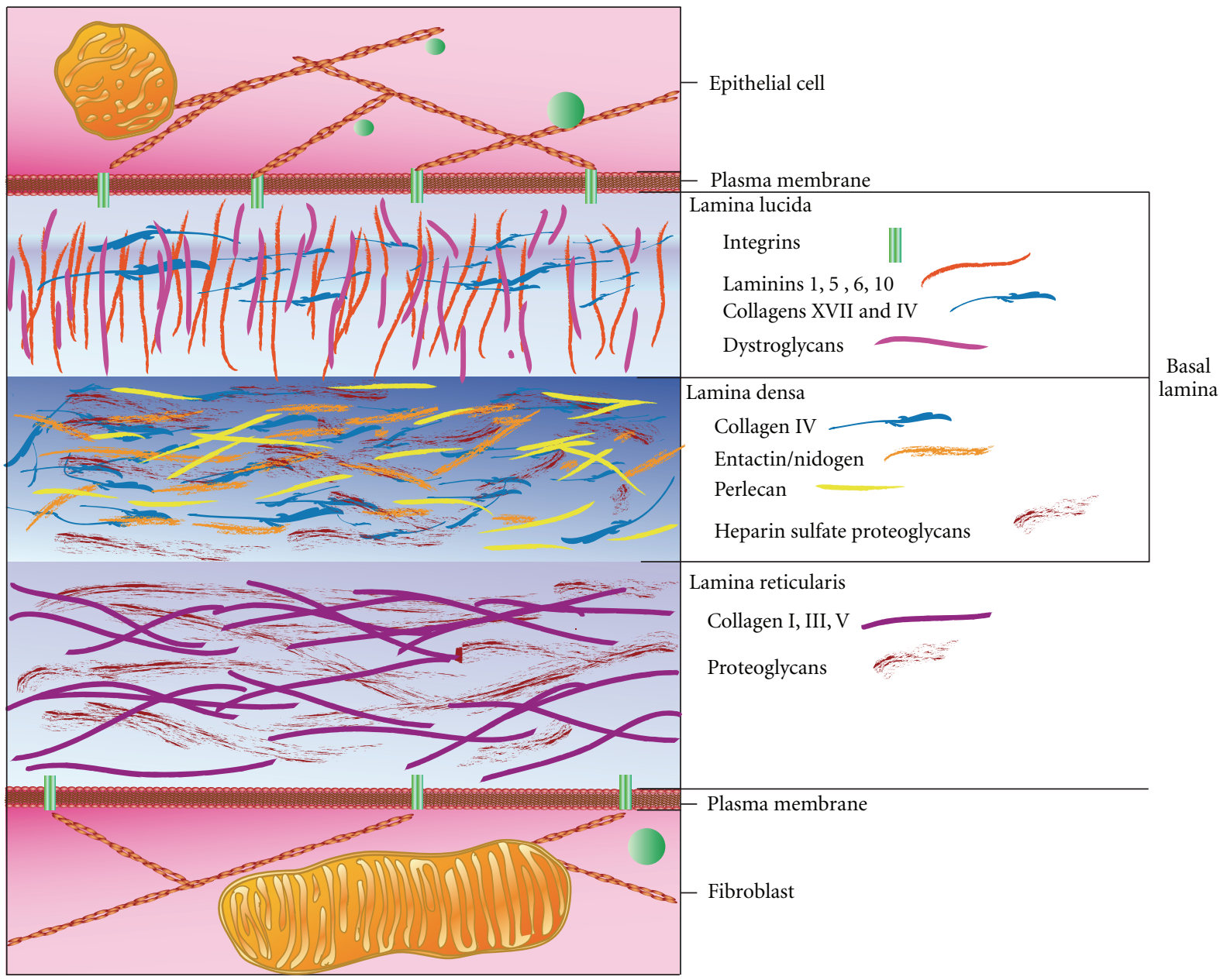

Figure 3: Basement membrane. The basement membrane underlies the typical cellular epithelium or vascular endothelium and consists of two thin structural layers. One layer is the basal lamina made by epithelial or endothelial cells. The second layer is the reticular lamina made by fibroblasts. Electron microscope data show that the basal lamina consists of a clear lamina lucida next to epithelial cells and an opaque lamina densa. The lamina lucida contains integrins, laminins (1, 5, 6 and 10), and collagen XVII, as well as type IV collagen, and dystroglycans. The lamina densa contains type IV collagen fibers, entactin/nidogen-1, perlecan, and heparan sulfate proteoglycans. The reticular lamina contains collagens I, III, and V and various proteoglycans. Invasion through the basement membrane requires the expression of many different cell surface adhesion receptors and matrix degrading enzymes.

$\beta$ subunits found in the $\mathrm{N}$-terminus of these receptors [107, 111-113]. Together the joined $\alpha$ and $\beta$ subunit termini form an N-terminal headpiece [111].

Three conformation states exist for $\alpha$ and $\beta$ subunit complexes [114-116]. The first conformation is usually unliganded with a closed headpiece and a bent receptor structure. In this case, the EGF domains of the $\beta$-subunit are juxtapositioned directly against the calf-1-calf- 2 domains in the support leg of the $\alpha$-subunit while the headpiece bends inward toward the plasma membrane $[107,111-113,116]$. Second, the integrin complex headpiece remains closed, but structural changes in the $\beta$-subunit EGF domains cause them to separate from the calf-1-calf- 2 domains of the $\alpha$-subunits and extend away from the plasma membrane [111, 114-116]. Third, altered conformation in the $\beta 6-\alpha 7$ loops exposes the ligand-binding site while the $\beta$-subunit completely separates from the calf-1-calf- 2 domains in the support leg of the $\alpha$ subunit. These cooperative conformational changes in the heterodimer structures enable the full engagement of a specific integrin headpiece with its ligand [111, 114-116]. These conformational changes can occur during the regulation of "outside-in signaling" $[117,118]$ or alternatively "inside-out signaling" $[112,119]$.

\section{Outside-In Signaling}

Similar to conventional cell surface signal transducing receptors, integrins bind ligands and transmit information in an "outside-in signaling" (Figure 5) [111, 112]. "Outsidein signaling" behavior typically involves the engagement of integrins with the extracellular matrix or ICAM surface receptors $[111,118-121]$. When external factors bind to 


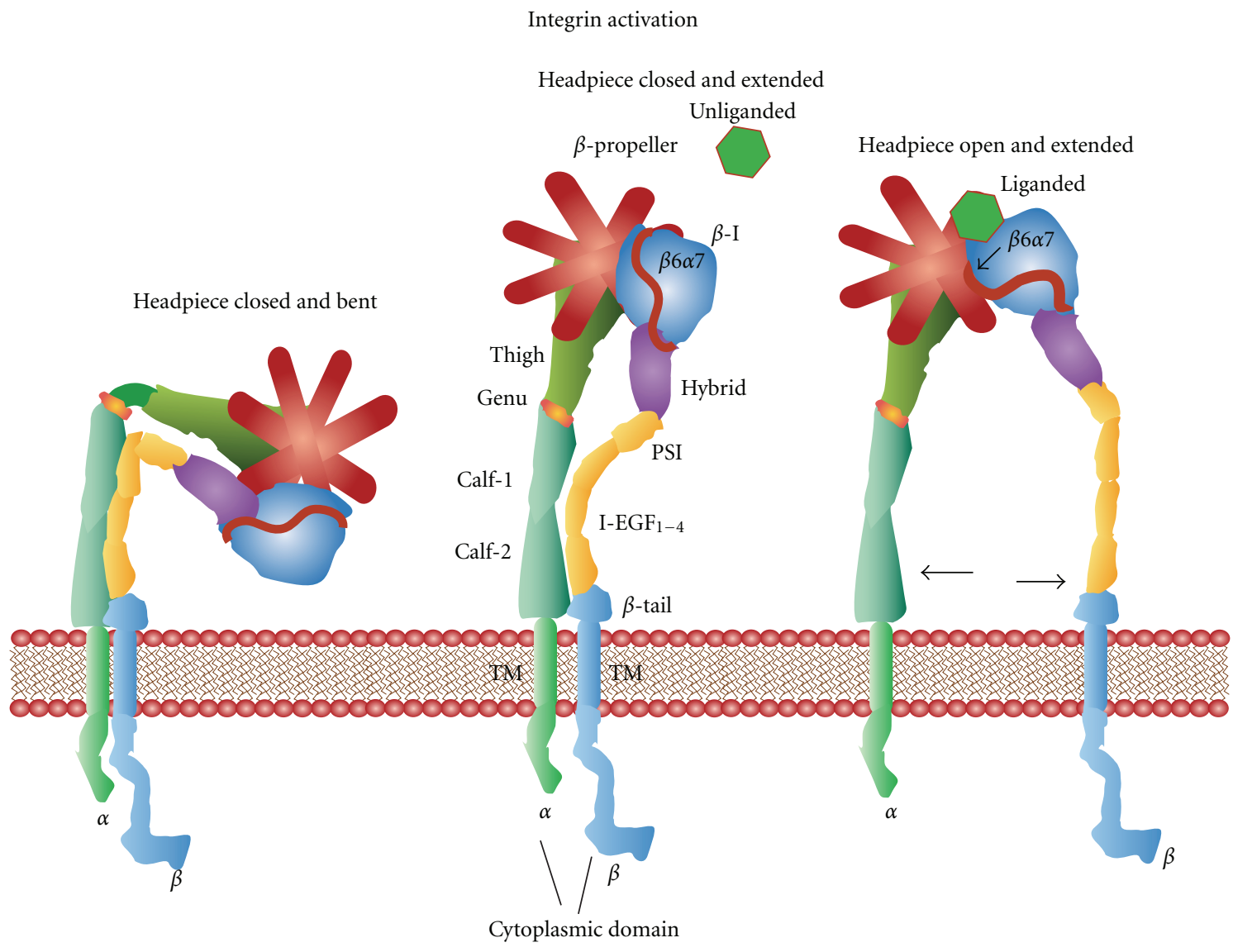

FIGURE 4: Integrins. Integrins are transmembrane glycoprotein adhesion receptor complexes consisting of $\alpha$ and $\beta$ subunits. The $\alpha$ subunit contains a seven-bladed $\beta$-propeller head domain connected to a leg support structure made of a thigh, a calf- 1 , a calf- 2 , a transmembrane, and a cytoplasmic domain that mediates ligand specificity. The $\beta$ subunit contains an N-terminal plexin-semaphorin-integrin (PSI) domain, a hybrid domain, a $\beta$-I domain, four cysteine-rich epidermal growth factor (EGF) repeats, a transmembrane, and a cytoplasmic domain that interacts with the cell cytoskeleton. The N-terminal $\beta$-I domain of a $\beta$ subunit inserts into the $\beta$-propeller domain of an $\alpha$ subunit forming a headpiece complex. The formation of integrin receptor complexes depends on divalent cation (i.e., $\left.\mathrm{Ca}^{2+}, \mathrm{Mn}^{2+}, \mathrm{Mg}^{2+}\right)$ that bind to metal-ion-dependent adhesion site (MIDAS) motifs in the $\alpha$ subunits and adjacent to MIDAS (ADMIDAS) motifs in $\beta$ subunits. Three conformation states exist for $\alpha$ and $\beta$ subunit complexes. (1) The unliganded conformation has a closed headpiece and a bent receptor structure with the EGF domains of the $\beta$-subunit touching the calf-1-calf- 2 domains of the $\alpha$-subunit. (2) The headpiece remains closed, but structural changes in the $\beta$-subunit EGF domains cause a separation from the calf-1-calf- 2 domains of the $\alpha$-subunits causing an extended structure. (3) Conformational changes in the $\beta_{6}-\alpha_{7}$ loops expose the ligand-binding site along with a complete separation of the $\beta$-subunit from the calf-1-calf- 2 domains in the $\alpha$-subunit. These conformational changes engage the specific integrin headpiece with its ligand.

exposed ligand binding site on integrins this results in conformational changes described in the previous section. Most ECM proteins exhibit multivalent or recurrent molecular patterns, which trigger integrin clustering. As cells engage the repetitive patterns in the ECM, these events occur simultaneously thereby activating intracellular signals. The myriad of different extracellular signals that cells encounter in their microenvironment mediates cell polarity, cytoskeletal structure, adhesion, migration, invasion, gene expression, cell survival, and proliferation.

In the case of "outside-in signaling" initiated by ECM proteins, a single ligand-binding event can trigger integrin activation, but repetitive regularly spaced molecular patterns provide a more effective stimulus $[122,123]$. This type of mechanoreception has been explored using nanopatterned molecular printing techniques that form regular cRGDfK patch spacings on a polyethylene glycol background matrix [122-125]. These adhesion-dependent sensory mechanisms lead to signal transduction inside the cell by the activating multiple pathways. Focal adhesions are often formed as a result of cell interactions with the ECM substrata, which initiate signal transduction via kinase cascades and other mechanisms.

\section{Integrins and Focal Adhesions}

Focal adhesions were first recognized in Rous sarcoma virustransformed normal rat kidney cells using an antitumor serum specific for pp60src, as a speckled pattern of fluorescence on the ventral surface (Figure 5) [126]. Focal adhesion kinase (FAK) is a well-studied integrin-activated protein tyrosine kinase (PTK) [127, 128]. FAK was identified as a pp125 


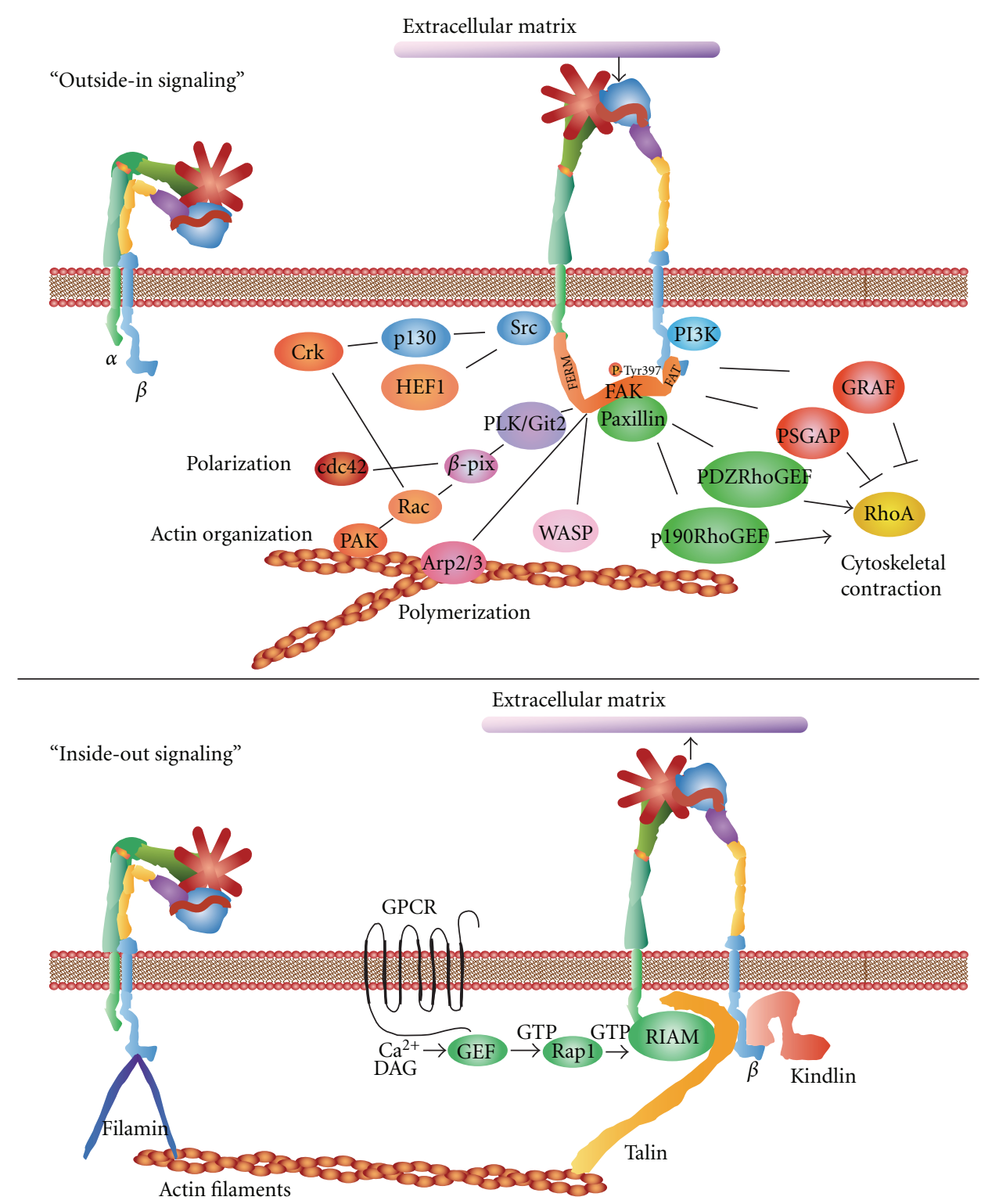

Figure 5: "Outside-in" and "Inside-out" signaling. The "outside-in" binding of ECM ligands to cell surface integrins stimulates conformational changes that activate focal adhesion kinase (FAK). FAK then is autophosphorylated on Tyrosine 397 near the catalytic domain, which binds Src. FAK contains a central kinase domain bordered by FERM (protein 4.1, ezrin, radixin, and moesin homology) domain at the N-terminus and a focal adhesion targeting (FAT) sequence at the C-terminus. Activated Src interacts with human enhancer of filamentation1 (HEF1) and p130 CRK-associated substrate (p130CAS) scaffold proteins that help to positively regulate Src-FAK-Crk interactions with Rac. FAK also activates (PKL/Git2)- $\beta$-Pix complexes and $\beta$-pix then serves either as an exchange factor for Cdc42 or a scaffold protein to promote signaling via Rac and p21-activated protein kinases (PAK). FAK also interacts with actin-related proteins (ARP2 and ARP3) which is regulated by the Wiskott-Aldrich Syndrome Protein (WASP). ARP2/ARP3 initiates the polymerization of new actin filaments. FAK also influences actin contraction and polarization through another GTPase protein, Rho. The regulation of Rho GTPase hydrolysis of GTP (active) to GDP (inactive) form occurs through the opposing activities of guanine nucleotide exchange factor (GEFs). GTPase regulator associated with FAK (GRAF) and p190RhoGAP blocks actin cytoskeleton changes. In contrast, PDZRhoGEF and p190RhoGEF both serve to activate Rho. "Outside-in signaling” transfers integrin-mediated external signals to the inside of cells. "Inside-out signaling" depends on talin and kindlin. Both talin and kindlin contain FERM (4.1/ezrin/radixin/moesin) domains and a highly conserved $\mathrm{C}$-terminal F3 domains. Talins bind $\beta$ integrin, actin through the $\mathrm{C}$-terminus, and also vinculin. Kindlins bind integrins, the cell membrane, and various actin adaptor proteins like migfilin, or integrin-linked kinase (ILK). Talin activation occurs through G-protein-coupled receptors that increases cytoplasmic $\mathrm{Ca}^{2+}$ and diacylglycerol. This activates GEF function in conjunction with Ras-proximate-1/Ras-related-protein-1(Rap1-) GTPase. Rap1 then binds to Rap1-GTP-interacting adaptor molecule (RIAM). RIAM recruits talin to the membrane and the $\alpha$ and $\beta$ integrin cytoplasmic domains. Kindlin interacts with $\beta$ integrin cytoplasmic domain stabilizing the activated state of the integrin complex. "Inside-out signaling" strengthens adhesive contacts and the appropriate force necessary for integrin-mediated cell migration, invasion, ECM remodeling, and matrix assembly. 


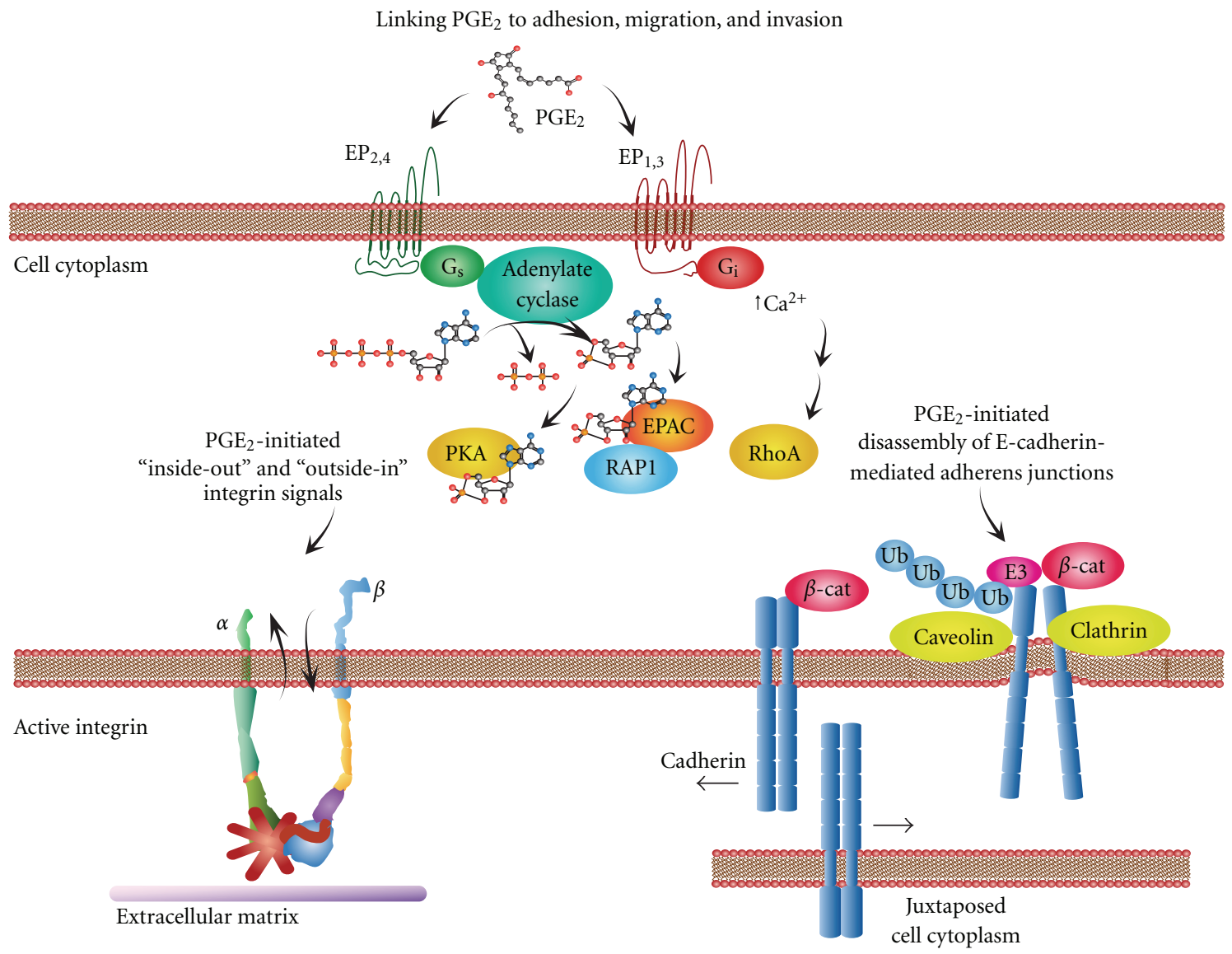

Figure 6: Linking $\mathrm{PGE}_{2}$ to adhesion, migration, and invasion. Prostaglandin $\mathrm{E}_{2}$ elicits profound changes in tumor cells that result in the disassociation of cadherin-mediated cell connections. This is accompanied by the establishment/turnover of integrin-mediated interactions with extracellular matrix during adhesion and subsequent migration and invasion. Stimulation of EP2 or 4 receptors leads to the activation of adenylate cyclase and results in the production of cyclic adenosine monophosphate (cAMP) from adenosine triphosphate (ATP). The accumulation of cAMP in the cell cytoplasm activates protein kinase A (PKA) and the phosphorylation of downstream targets. This accumulation of cAMP can also activate exchange protein activated by cAMP (Epac). The activation of Epac may involve the interactions with Rap1 and subsequent downstream signals that influence adhesion, migration, and invasion. The activation of EP1 and EP3 leads to Ca ${ }^{2+}$ influx and the activation of Rho-mediated signal transduction that influences cadherin function during the disassociation of cadherin-based adhesive contacts or integrin interactions with the extracellular matrix contacts.

tyrosine-phosphoprotein in untransformed chicken embryo cells that increased in pp60v-src-transformed chicken embryo cells [129]. FAK is nonmembrane associated cytoplasmic protein that is autophosphorylated on Tyrosine 397 located at the juncture of the N-terminal and catalytic domains, which directs SH2-dependent binding of pp60src [130]. FAK contains a central kinase domain flanked by FERM (protein 4.1, ezrin, radixin, and moesin homology) domain at the N-terminus and a focal adhesion targeting (FAT) sequence at the C-terminus, which drives localization to focal adhesions $[131,132]$. Upon interacting with the cyto-plasmic domains of integrins, autophosphorylated FAK interacts with numerous proteins recruited to focal adhesions. It can affect actin organization through the phosphorylation of paxillin $[133,134]$. Paxillin phosphorylation by FAK on tyrosine residues 31 and 118 creates binding sites for the Src homology-2 (SH2) domains of adaptor proteins Crk, Csk, and Src [133]. Human enhancer of filamentation1
(HEF1) and p130 CRK-associated substrate (p130CAS) are scaffold proteins that help to positively regulate Src-FAKCrk interactions $[135,136]$. Paxillin can also interact with paxillin kinase linker- (PKL/Git2-) $\beta$-pix complexes [137]. $\beta$-pix functions as an exchange factor for Cdc42 or serves as a scaffold protein to promote signaling via the Rho family GTPase Rac and p21-activated protein kinases-(PAK) [137]. FAK-mediated regulation of Cdc42 and Rac activity asserts control over the extension of lamellipodia and cell migration as well as cellular polarization.

As another pathway influenced by FAK, interactions with actin-related proteins (ARP2 and ARP3) either occur directly or are regulated by the Wiskott-Aldrich Syndrome Protein (WASP) [132]. ARP2/ARP3 closely resembles the structure of monomeric actin. ARP2/ARP3 complexes serve as nucleation sites for new actin filaments [138]. When RP2/ ARP3 complexes bind to the sides of preexisting actin filaments, they initiate the polymerization of new filaments 
at a uniform $70^{\circ}$ degree-angle during cytoskeletal rearrangements [138]. These molecular activities help organize and expand growing cytoskeletal meshworks of actin filaments.

FAK also influences actin contraction and polarization through another GTPase protein, Rho. The regulation of Rho GTPase hydrolysis of GTP (active) to GDP (inactive) form occurs through the opposing functions of GTPaseactivating proteins (GAPs) or guanine nucleotide exchange factors (GEFs) [139]. GAPs make GTP a better substrate for nucleophilic attack thereby lowering the transition state energy for hydrolysis to GDP, inactivating Rho. In contrast, GEFs stimulate the release of GDP from Rho and accelerate the binding of GTP, thereby activating Rho. Among the Rho-inactivating GAP proteins is one that binds to the Cterminal domain of FAK, GTPase regulator associated with FAK (GRAF) to block actin cytoskeleton changes [140]. Another GAP protein, p190RhoGAP, can bind to complexes with p190RasGAP and FAK that alter the cytoskeleton [141]. In contrast, PDZRhoGEF and p190RhoGEF both serve to activate Rho. This activation promotes focal-adhesion turnover and their relocalization within the cell along with cell migration $[142,143]$.

\section{Prostaglandins and Focal Adhesion Kinase}

"Outside-in" stimulation by adhesion to ECM also stimulates PG pathway activity and FAK activity (Figure 5). When Hela or NIH3T3 cells are allowed to adhere to ECM, elevations in COX and PKA stimulate the formation of actin bundles that contain myosin II and associate with small focal adhesions and increase cell motility [144]. Similarly, stimulation of Raw264.7 cells with bovine type I collagen increased cyclicAMP response element-binding protein (CREB) binding to DNA along with COX-2 expression that was reversed by inhibition of FAK [145]. Fluid shear stress stimulation of mechanoreceptors and RDGS mediated disruption of fibronectin adhesions-induced formation of focal adhesions and promoted the upregulation of COX-2 and $\mathrm{PGE}_{2}$ release [146]. Similarly, mechanostimulation of osteoblasts activated FAK and $\mathrm{PGE}_{2}$ release via integrin stimulation, which increased F-actin fiber formation, causing increased cell stiffness [147, 148]. Furthermore, HEF-1 adaptor proteins that positively regulate interactions with FAK are upregulated by $\mathrm{PGE}_{2}$ and stimulate cancer cell migration [149].

Prostaglandins have a profound impact on FAK, immune cells, and cancer. This can occur by stimulation with a variety of PGs. For example, in 293-EBNA (Epstein-Barr nuclear antigen) cells stably expressing prostaglandin $\mathrm{F}_{2 \alpha}\left(\mathrm{PGF}_{2 \alpha}\right)$ receptors 1 or 2 , stimulation with $\mathrm{PGF}_{2 \alpha}$ causes morphological and cytoskeletal changes [150]. The phosphorylation of FAK occurs in association with Rho-mediated morphological and cytoskeletal changes within two minutes, highlighting the rapidness of this process [150]. This FAKmediated response to $\mathrm{PGF}_{2 \alpha}$ has also been observed in HEK293 cells [151] and endometrial adenocarcinoma cells [152]. Prostaglandin $\mathrm{E}_{2}$ is also a strong stimulus for FAK activity. In hepatocellular carcinoma cells for example, $\mathrm{PGE}_{2}$ increases the phosphorylation and synthesis of FAK in a dose-dependent manner [153]. Thus PG ligand binding to cognate GPCRs can also initiate "inside-out signaling".

\section{Inside-Out Signaling}

"Inside-out signaling" depends on a intracellular activators (Figure 5) [119]. These intracellular activators include proteins such as talin or kindlins [120, 154]. There are two talin isoforms and three kindlin isoforms identified thus far [154]. Both talin and kindlin contain FERM (4.1/ezrin/radixin/moesin) domains and a highly conserved C-terminal F3 domain [154]. Talins contain binding sites for several $\beta$ integrin cytodomains, a highly conserved $C$ terminal actin-binding site and also VBS (vinculin-binding site) $[119,120]$. Kindlins contain $\beta$ integrin cytodomainbinding sites in their F3 domains, membrane-binding domains and a C-terminus that interacts with integrins, various actin adaptor proteins like migfilin, or integrinlinked kinase (ILK) [120, 154]. The activation process is thought to begin following stimulation of G-protein-coupled receptors that cause increases in cytoplasmic $\mathrm{Ca}^{2+}$ and diacylglycerol, followed by GEF activation in conjunction with Ras-proximate-1/Ras-related protein 1 (Rap1)-GTPase $[119,120]$. Rap1 then binds to Rap1-GTP-interacting adaptor molecule (RIAM) [155]. RIAM is the believed to recruit talin to the membrane and the $\alpha$ and $\beta$ integrin cytoplasmic domains [119]. Alternatively, talin interacts with PIPKI $\gamma /$ PIP2 and then is cleaved by calpain [119]. Kindlin also interacts with the $\beta$ integrin cytoplasmic domain stabilizing the activated state of the integrin complex [119]. "Inside-out signaling" strengthens integrin-mediated adhesion with extracellular ligands that transfers the appropriate force necessary for cell migration, invasion, ECM remodeling, and matrix assembly [119].

\section{Prostaglandins, Integrins, and Angiogenesis}

Prostaglandins are known to regulate cellular interactions with extracellular matrix and angiogenesis as early events in cancer progression [1] (Figure 6). The overexpression of COX-2 in rat intestinal epithelial cells was shown to increase adhesion to ECM and inhibit apoptosis which was reversed by sulindac sulfide (a COX inhibitor) [88]. COX-2 also plays a key role in endothelial cell migration and tube formation that relies on interactions with ECM during angiogenesis, which was reversed by NS398 (a COX-2 inhibitor) [156]. Prostaglandin $\mathrm{E}_{2}$ plays an important role in stimulating the angiogenic behavior of endothelial cells [157-162]. By contrast, $\mathrm{PGE}_{1}$ (alprostadil) inhibits angiogenesis in vitro and in vivo in the murine Matrigel plug assay [163]. Much of the migratory and invasive behavior of endothelial cells is regulated by signal transducing integrins that initiate changes in cellular shape, adhesion, and motility. For example, endothelial cell migration involves $\alpha_{V} \beta_{3}$ (vitronectin) and $\alpha_{5} \beta_{1}$ (fibronectin) integrin function, COX-2, the genesis of cAMP involving protein kinase $\mathrm{A}[164,165]$. This promotion of integrin $\alpha_{V} \beta_{3}$ integrin-mediated endothelial cell adhesion, spreading, migration, and angiogenesis appears to occur 
through COX-2-prostaglandin-cAMP-PKA-dependent activation of the small GTPase Rac [165-167]. Others also confirmed the involvement of $\alpha_{3} \beta_{1}$ receptors [168]. Distinct integrins such as $\alpha_{6} \beta_{1}$ (laminin) or $\alpha_{1} \beta_{1}$ and $\alpha_{2} \beta_{1}$ (collagen) receptors are also involved in the migration and invasion of endothelial cells during angiogenesis [169-175]. These studies highlight the role of PG-initiated responses by endothelial cells that involve integrins during the angiogenesis.

\section{Prostaglandins, Integrins, and Tumor Cell Invasion}

Tumor cells also migrate and invade through the basement membrane in response to stimulation by $\mathrm{PGE}_{2}$ (Figure 6). For example, $\mathrm{PGE}_{2}$ treatment of LS-174T human colorectal carcinoma cells leads to increased motility and changes in cell shape that involves stimulation of the prostaglandin EP4 receptor [176]. In another colon cancer cell line, $\mathrm{CaCo} 2$ cell adhesion to type I collagen via $\alpha_{2} \beta_{1}$ integrins was stimulated by $\mathrm{PGE}_{2}$ and inhibited by COX-2 inhibitors [177]. Similarly, colon cancer cells expressing $\beta_{1}$ integrin levels along with COX-2 inhibition decreased adhesion and migration on ECM [178]. In another study using breast cancer cells, laminin receptor $\left(\alpha_{3} \beta_{1}\right)$ binding to laminin-peptide PA-22 was reduced by $\mathrm{PGE}_{2}$ receptor antagonist (LEO101) [179]. Similarly, the suppression of integrin $\alpha_{3} \beta_{1}$ in breast cancer cells reduced COX-2 gene expression and inhibited tumorigenesis and invasion [168]. In the case of lung cancer, FN stimulated cell proliferation through an $\alpha_{5} \beta_{1}$ (fibronectin) integrin-mediated process in conjunction with increases in COX-2 and $\mathrm{PGE}_{2}$ biosynthesis that was blocked by NS-398 (a COX-2 inhibitor) [180]. The upregulation of COX-2 also induces tumor cell invasion in models of pancreatic cancer [181]. Other eicosanoids also influence integrin-mediated adhesion and invasion $[182,183]$. Collectively, these studies highlight the importance of PGs during integrin-mediated adhesion, migration, and invasion through extracellular matrices by tumor cells.

\section{Prostaglandins and CNN Proteins}

Prostaglandins also regulate the production of matricellular proteins of the CCN family (CYR61/CTGF/NOV) that are emerging as major contributors to chronic inflammatory diseases and regulators of ECM [184]. CCN is an acronym that describes the first three protein family members identified out of six total: CYR61/CCN1 (cystein-rich 61;[185]), CTGF/CCN2 (connective tissue growth factor; [186]), and NOV/CCN3 (nephroblastoma overexpressed; [187]). The other family members consist of structurally conserved secreted multitasking Wnt-inducible secreted proteins (WISP-1/CCN4, WISP-2/CCN5, and WISP-3/CCN6) [188]. Each family member interacts with a specific subset of integrins and can be induced by $\mathrm{PGE}_{2}$ depending on the cellular context [184]. In many instances, cell stimulation involving CCNs can alter the production of matrix metalloproteinases [184]. CCN proteins regulate cell adhesion, migration, proliferation, and inflammatory responses that are influenced by PGs [184].

\section{Prostaglandins and Cell Surface Proteoglycans}

Proteoglycans are very heavily glycosylated proteins on the surfaces of cells that heavily influence cell signal transduction and behavior [94, 189-194]. Proteoglycans exert profound control over various aspects of wound healing, angiogenesis, and cancer spreading [192, 195]. The fundamental proteoglycan unit contains a "core protein" and one or more covalently coupled glycosaminoglycans [190, 191]. Coupling occurs through a serine residue to a saccharide bridge found in the glycosaminoglycan. Glycosaminoglycan carbohydrate structures include chondroitin sulfate, dermatan sulfate, heparin sulfate, and keratin sulfate. Proteoglycans fall into two major categories based on size. Small proteoglycans range in molecular weight between 36 to $66 \mathrm{kDa}$ and include decorin, biglycan, testican, fibromodulin, lumican, syndecan, and glypican. Large proteoglycans achieve molecular weights between 136 to $470 \mathrm{kDa}$ and include versican, perlecan, neurocan, and aggrecan within this category. Proteoglycans cooperate dynamically with integrins and growth factors to local adhesion sites or signal complexes to integrate of both external and internal signals [196]. Together with prostaglandins, proteoglycans facilitate adhesion and migration and tubulogenesis by primary endothelial cells and promote phosphorylation of signaling molecules such as Akt and Src $[94,197]$. Prostaglandins in concert with proteoglycans also promote the recruitment of stromal cells from the bone marrow to the developing tumor microenvironment [198, 199]. These include CXCL12, CXCR4, and S100A4 producing fibroblasts that involve signaling through a COX-2/PGE 2 EP3/EP4-dependent pathway [199]. Similarly, the combined effect of prostaglandins and proteoglycans regulates the transition from immature dendritic cells (iDCs) to mature DCs (mDCs) [198]. In breast cancer cells, prostaglandins and proteoglycans stimulate invasion across a basement membrane and induces synthesis of specific heparin-binding splice variants of vascular endothelial cell growth factor (VEGF) [200]. In like fashion, the malignant transformation of intestinal epithelial cells induces the production of VEGF that involves Ras pathway activation [160]. Among the proteoglycans, perlecan in particular plays an integral role in extracellular matrix deposition in response to $\mathrm{PGE}_{2}$ [201]. Perlecan is also upregulated during tumor-associated angiogenesis [202], which can be inhibited by decreasing perlecan synthesis [203]. As a whole, proteoglycans work together with prostaglandins to regulate tumor growth and angiogenesis.

\section{Prostaglandins and Tetraspanins}

Tetraspanins form a family of 33 membrane proteins that contain 4 transmembrane-spanning domains [204]. They play important roles in cell adhesion, motility, invasion, immunity, and tumor progression [205-209]. Among these 
tetraspanins, CD151, CD9, Tspan12, and KITENIN are most known for their role in cancer [205-208, 210]. Tetraspanin CD151 interacts with laminin-binding integrins $\alpha 6 \beta 1$ and $\alpha 6 \beta 4$ to regulate signal transduction activity during growth, migration, invasion, and metastasis $[211,212]$. Tetraspanin CD9 in cooperation with cell-surface Ig superfamily proteins, EWI-2 and EWI-F acts to suppress tumorigenesis [213-215]. Tspan 12 interacts with a disintegrin and metalloprotease 10 (ADAM10) to initiate protumorigenic functions [216, 217]. Also, KAI1 COOH-terminal interacting tetraspanin (KITENIN) contributes to tumor invasion and metastasis in human colorectal cancers [210] and gastric cancer [218]. In the case of interactions with prostaglandins, prostaglandin $\mathrm{F}_{2}$ receptor-associated protein (FPRP) is frequently involved in binding to cancer cell tetraspanins $[219,220]$. However, the direct regulation of this class of adhesion related molecules by prostaglandins or eicosanoids remains unknown.

\section{Recent Advances in Prostaglandin and Adhesion-Based Cancer Therapy}

Since (COX-2) is the rate-limiting enzyme in prostaglandin synthesis, it is an effective intervention point for inhibitors [221]. It is well documented that elevated COX-2 levels drive chronic inflammation and carcinogenesis [1]. Clinical and epidemiologic studies clearly demonstrate a significant benefit from inhibiting COX-2 in colon cancer [221, 222]. Unfortunately, COX-2 inhibition is associated with cardiovascular toxicity in a subpopulation of patients at high risk for cardiovascular disease [221, 222]. Nonetheless, this pathway remains an excellent target, based on very strong evidence that the upregulation of COX-2-mediated inflammatory mediators mediates many different cancers [1].

Selective COX-2 inhibition can also initiate a shunt of AA-based substrates to the 5-lipoxygnease (5-LOX) pathway [223], Based on these and other findings, a number of dual pathway inhibitors have been developed that appear to exhibit less toxicity [224-227]. Licofelone is a 5-LOX/COX inhibitor that was developed to treat inflammation and osteoarthritis [228, 229]. In osteoarthritis clinical trials, licofelone inhibits COX and 5-LOX and has low GI toxicity [230, 231]. In another osteoarthritis study, licofelone reduced osteoarthritis symptoms and less cartilage loss by MRI than naproxen [232]. Although developed and tested in osteoarthritis patients, cancer prevention is also an important target. In a lung carcinogenesis mouse model, for example, licofelone showed a dose-dependent inhibition of Cox-2 and 5-Lox and proliferating cell nuclear antigen (PCNA) staining in concert with an increase in apoptosis [233]. An overall reduction in GI toxicity in combination with enhanced anti-inflammatory activity makes these new inhibitors a promising class of compounds for the prevention and treatment of cancer.

Another approach is to specifically target specific points in the proinflammatory and procarcinogenic mPGES1$\mathrm{PGE}_{2}-\mathrm{EP} 1-4$ axis of the COX-2 pathway [221]. Inhibition of the inducible mPGES-1 has received significant attention
$[14,15,22,23,234]$. In mouse models, $\operatorname{EP}(1)$ and $\operatorname{EP}(3)$ receptor antagonists ONO-8713 and ONO-AE3-240, but not the $\mathrm{EP}(4)$ antagonists ONO-AE3-208 and AH 23848, inhibited medulloblastoma tumor cell proliferation [235]. In $\mathrm{Apc}^{\mathrm{Min} \backslash+}$ models of colon carcinogenesis, by contrast, the genetic deletion of mPGES-1 significantly protected against azoxymethane-induced colon cancer [236]. In these studies genetic the deletion mPGES-1 reduced tumor multiplicity by $\sim 80 \%$ and tumor load by $90 \%$ [236]. Also in a syngeneic mouse model of bone cancer, mPGES-1 enhances tumor growth and associated pain [237]. These studies emphasize the importance of mPGES-1 as a target for cancer prevention and therapy.

As a target further downstream, methods to decrease the accumulation of $\mathrm{PGE}_{2}$ in tumors are also a potential target option. In this case, treatment may include enhancing the metabolic turnover of PGs by 15-PGDH. This may require upregulation by reversing histone deacetylasemediated silencing of 15-PGDH [39]. These approaches are not as well developed as others but remain viable options for reducing prostaglandin-associated inflammation and cancer treatment.

As a target even further downstream, the development of EP selective receptor antagonists has seen extensive focus $[238,239]$. In mouse models, ONO-AE3-208, an EP4 receptor antagonist significantly reduced metastasis [240]. Another EP4 antagonist is being tested as an inhibitor of migraine headache [241]. Selectively targeting the mPGES1$\mathrm{PGE}_{2}$-EP1-4 arm of this pathway will likely avoid cardiovascular and GI toxicity attributed to selective targeting of COX2 alone. By combining targeting of the mPGES1-PGE2-EP1-4 axis with selective adhesion-based therapy, it may be possible to significantly impact cancer prevention and therapy.

Adhesion-based therapy is generally targeted directly at surface receptors or the signal transduction pathways that mediate their activation [242]. In the case of direct integrin targeting, for example, Phase II clinical trials with cilengitide, a cyclicized arginine-glycine-aspartic acid(RGD-)containing pentapeptide that acts as a $\alpha_{V} \beta 3$ and $\alpha_{V} \beta 5$ integrin antagonist, demonstrated clinical activity with limited side effects in glioblastoma patients [243, 244]. Based on these clinical results, the first Phase III clinical trial was initiated with an integrin antagonist [243, 244]. Similarly, $\alpha_{5} \beta_{1}$ integrins are also inhibited by the RGD amino acid sequence $[245,246]$, while $\alpha_{4} \beta_{1}$ are targeted by EILDV and REDV sequences [247]. In the case of cadherin targeting, ADH-1 is a cyclic pentapeptide that disrupts $\mathrm{N}$ cadherin adhesion complexes that is being used to treat melanoma [248-250]. In Phase I studies ADH-1 used in combination with melphalan is well tolerated after isolated limb perfusion to treat regionally advanced melanoma. This approach using ADH-1 is believed to help overcome melanoma chemoresistance [250]. As we enter an era of personalized cancer therapy, using peptides to target specific adhesion receptors may be a viable adjuvant for selective targeting.

Targeting the signal transduction pathways downstream of adhesion receptor signaling involves a variety of molecular targets. These include the kinases, phosphatases GAP, GEF, 
Rho family GTPases, adapter molecules, and scaffolding proteins among others. In the case of kinase targets, Src is a good candidate [251]. Src protein family members are useful because they serve as starting points for multiple signaling cascades involved in extracellular sensory activity [251]. This class of drugs includes the following: Bosutinib, AZD0530, and Dasatinib that target both cadherin/p120 catenin which affects adherens junctions [251]. Simultaneously, these compounds can affect integrin/FAK p130Cas, paxillin, and Rho, a downstream that affects interactions with ECM [251]. Preclinically for instance, AZD053 prevents phosphorylation of paxillin and FAK and suppresses metastasis in vivo [251].

Another effective kinase adhesion target is FAK [252, 253]. One of the most promising FAK inhibitors is PND1186, which blocks FAK Tyr-397 phosphorylation [254-256]. In vitro, PND-1186 blocks FAK tyrosine phosphorylation while activating caspase- 3 and initiating breast tumor cell apoptosis [255]. PND-1186 has also been tested in vivo and inhibits the growth of orthotopic breast carcinoma mouse models [254]. Targeting kinase molecules or the other intracellular signal pathway molecules may exhibit off-target effects that can be beneficial or cause unwanted side effects. Identifying patients with limited risk that will derive the most benefit from a given approach is essential to successful treatment.

In summary, targeting cell adhesion holds great promise for cancer therapy. As we learn more about individualizing cancer therapy, identifying patients that would receive the most benefit will help to direct targeting. For example, targeting specific adhesion pathways could be combined with inhibiting the mPGES1-PGE $-\mathrm{EP} 1-4$ axis in patients that also have elevated COX-2 in their tumors or elevated $\mathrm{PGE}_{2}$ metabolites in their blood and/or urine. This approach may serve as an effective means of personalizing treatment or providing specifically targeted adjuvant therapy.

\section{Acknowledgments}

This research was supported in part by NCI MERIT award R37 DK47297, NCI P01 CA77839, CPRIT-RP100960 Award, Ellen F. Knisely Distinguished Chair in Colon Cancer Research, and the National Colorectal Cancer Research Alliance to R. N. DuBois.

\section{References}

[1] D. Wang and R. N. Dubois, "Eicosanoids and cancer," Nature Reviews Cancer, vol. 10, no. 3, pp. 181-193, 2010.

[2] H. Shindou, D. Hishikawa, T. Harayama, K. Yuki, and T. Shimizu, "Recent progress on acyl CoA: lysophospholipid acyltransferase research," Journal of Lipid Research, vol. 50, pp. S46-51, 2009.

[3] H. Shindou and T. Shimizu, "Acyl-CoA: lysophospholipid acyltransferases," The Journal of Biological Chemistry, vol. 284, no. 1, pp. 1-5, 2009.

[4] J. M. Ellis, J. L. Frahm, L. O. Li, and R. A. Coleman, "Acylcoenzyme A synthetases in metabolic control," Current Opinion in Lipidology, vol. 21, no. 3, pp. 212-217, 2010.
[5] C. C. Leslie, "Regulation of the specific release of arachidonic acid by cytosolic phospholipase $\mathrm{A}_{2}$," Prostaglandins Leukotrienes and Essential Fatty Acids, vol. 70, no. 4, pp. 373376, 2004.

[6] W. Y. Ong, T. Farooqui, and A. A. Farooqui, "Involvement of cytosolic phospholipase $A_{2}$, calcium independent phospholipase $\mathrm{A}_{2}$ and plasmalogen selective phospholipase $\mathrm{A}_{2}$ in neurodegenerative and neuropsychiatric conditions," Current Medicinal Chemistry, vol. 17, no. 25, pp. 2746-2763, 2010.

[7] A. O. Rosa and S. I. Rapoport, "Intracellular- and extracellular-derived $\mathrm{Ca}^{2+}$ influence phospholipase $\mathrm{A}_{2}$-mediated fatty acid release from brain phospholipids," Biochimica et Biophysica Acta, vol. 1791, no. 8, pp. 697-705, 2009.

[8] S. B. Hooks and B. S. Cummings, "Role of $\mathrm{Ca}^{2+}$-independent phospholipase $\mathrm{A}_{2}$ in cell growth and signaling," Biochemical Pharmacology, vol. 76, no. 9, pp. 1059-1067, 2008.

[9] K. C. Duggan, M. J. Walters, J. Musee et al., "Molecular basis for cyclooxygenase inhibition by the non-steroidal anti-inflammatory drug naproxen," The Journal of Biological Chemistry, vol. 285, no. 45, pp. 34950-34959, 2010.

[10] C. A. Rouzer and L. J. Marnett, "Cyclooxygenases: structural and functional insights," Journal of Lipid Research, vol. 50, pp. S29-S34, 2009.

[11] Y. Urade, "Structure and function of prostaglandin D synthase," Tanpakushitsu Kakusan Koso, vol. 53, no. 3, pp. 217226, 2008.

[12] M. K. O’Banion, "Prostaglandin $\mathrm{E}_{2}$ synthases in neurologic homeostasis and disease," Prostaglandins and Other Lipid Mediators, vol. 91, no. 3-4, pp. 113-117, 2010.

[13] A. A. Romanovsky, A. I. Ivanov, and S. R. Petersen, "Microsomal prostaglandin E synthase-1, ephrins, and ephrin kinases as suspected therapeutic targets in arthritis: exposed by 'criminal profiling," Annals of the New York Academy of Sciences, vol. 1069, pp. 183-194, 2006.

[14] I. Kudo and M. Murakami, "Prostaglandin E synthase, a terminal enzyme for prostaglandin $\mathrm{E}_{2}$ biosynthesis," Journal of Biochemistry and Molecular Biology, vol. 38, no. 6, pp. 633638, 2005.

[15] A. V. Sampey, S. Monrad, and L. J. Crofford, "Microsomal prostaglandin E synthase-1: the inducible synthase for prostaglandin $\mathrm{E}_{2}$," Arthritis Research and Therapy, vol. 7, no. 3, pp. 114-117, 2005.

[16] H. Fahmi, "mPGES-1 as a novel target for arthritis," Current Opinion in Rheumatology, vol. 16, no. 5, pp. 623-627, 2004.

[17] T. Suzuki, Y. Fujii, M. Miyano, L. Y. Chen, T. Takahashi, and K. Watanabe, "cDNA cloning, expression, and mutagenesis study of liver-type prostaglandin F synthase," The Journal of Biological Chemistry, vol. 274, no. 1, pp. 241-248, 1999.

[18] T. Nakayama, "Genetic polymorphisms of prostacyclin synthase gene and cardiovascular disease," International Angiology, vol. 29, no. 2, pp. 33-42, 2010.

[19] K. H. Ruan and J. M. Dogné, "Implications of the molecular basis of prostacyclin biosynthesis and signaling in pharmaceutical designs," Current Pharmaceutical Design, vol. 12, no. 8, pp. 925-941, 2006.

[20] C. Kontogiorgis and D. Hadjipavlou-Litina, "Thromboxane synthase inhibitors and thromboxane $\mathrm{A}_{2}$ receptor antagonists: a quantitative structure activity relationships (QSARs) analysis," Current Medicinal Chemistry, vol. 17, no. 28, pp. 3162-3214, 2010.

[21] J. Guay, K. Bateman, R. Gordon, J. Mancini, and D. Riendeau, "Carrageenan-induced paw edema in rat elicits a predominant prostaglandin $\mathrm{E}_{2}\left(\mathrm{PGE}_{2}\right)$ response in the central nervous 
system associated with the induction of microsomal $\mathrm{PGE}_{2}$ synthase-1," The Journal of Biological Chemistry, vol. 279, no. 23, pp. 24866-24872, 2004.

[22] M. Nakanishi, V. Gokhale, E. J. Meuillet, and D. W. Rosenberg, "mPGES-1 as a target for cancer suppression: a comprehensive invited review 'Phospholipase $A_{2}$ and lipid mediators'” Biochimie, vol. 92, no. 6, pp. 660-664, 2010.

[23] D. Kamei, M. Murakami, Y. Sasaki et al., "Microsomal prostaglandin E synthase-1 in both cancer cells and hosts contributes to tumour growth, invasion and metastasis," Biochemical Journal, vol. 425, no. 2, pp. 361-371, 2010.

[24] C. E. Eberhart, R. J. Coffey, A. Radhika, F. M. Giardiello, S. Ferrenbach, and R. N. DuBois, "Up-regulation of cyclooxygenase 2 gene expression in human colorectal adenomas and adenocarcinomas," Gastroenterology, vol. 107, no. 4, pp. 1183-1188, 1994.

[25] C. S. Williams, C. Luongo, A. Radhika et al., "Elevated cyclooxygenase-2 levels in Min mouse adenomas," Gastroenterology, vol. 111, no. 4, pp. 1134-1140, 1996.

[26] K. Yoshimatsu, D. Golijanin, P. B. Paty et al., "Inducible microsomal prostaglandin $\mathrm{E}$ synthase is overexpressed in colorectal adenomas and cancer," Clinical Cancer Research, vol. 7, no. 12, pp. 3971-3976, 2001.

[27] C. A. Ritter, G. Jedlitschky, H. Meyer zu Schwabedissen, M. Grube, K. Köck, and H. K. Kroemer, "Cellular export of drugs and signaling molecules by the ATP-binding cassette transporters MRP4 (ABCC4) and MRP5 (ABCC5)," Drug Metabolism Reviews, vol. 37, no. 1, pp. 253-278, 2005.

[28] K. Takeuchi, S. Kato, and K. Amagase, "Prostaglandin EP receptors involved in modulating gastrointestinal mucosal integrity," Journal of Pharmacological Sciences, vol. 114, no. 3, pp. 248-261, 2010.

[29] Y. Sugimoto and S. Narumiya, "Prostaglandin E receptors," The Journal of Biological Chemistry, vol. 282, no. 16, pp. 11613-11617, 2007.

[30] F. G. Buchanan, D. L. Gorden, P. Matta, Q. Shi, L. M. Matrisian, and R. N. DuBois, "Role of $\beta$-arrestin 1 in the metastatic progression of colorectal cancer," Proceedings of the National Academy of Sciences of the United States of America, vol. 103, no. 5, pp. 1492-1497, 2006.

[31] F. G. Buchanan, V. Holla, S. Katkuri, P. Matta, and R. N. DuBois, "Targeting cyclooxygenase-2 and the epidermal growth factor receptor for the prevention and treatment of intestinal cancer," Cancer Research, vol. 67, no. 19, pp. 9380 9388, 2007.

[32] F. G. Buchanan, D. Wang, F. Bargiacchi, and R. N. DuBois, "Prostaglandin $\mathrm{E}_{2}$ regulates cell migration via the intracellular activation of the epidermal growth factor receptor," The Journal of Biological Chemistry, vol. 278, no. 37, pp. 3545135457, 2003.

[33] R. A. Gupta, J. A. Brockman, P. Sarraf, T. M. Willson, and R. N. DuBois, "Target genes of peroxisome proliferator-activated receptor $\gamma$ in colorectal cancer cells," The Journal of Biological Chemistry, vol. 276, no. 32, pp. 29681-29687, 2001.

[34] R. A. Gupta, J. Tan, W. F. Krause et al., "Prostacyclin-mediated activation of peroxisome proliferator-activated receptor $\delta$ in colorectal cancer," Proceedings of the National Academy of Sciences of the United States of America, vol. 97, no. 24, pp. 13275-13280, 2000.

[35] V. R. Holla, M. G. Backlund, P. Yang, R. A. Newman, and R. N. DuBois, "Regulation of prostaglandin transporters in colorectal neoplasia," Cancer Prevention Research, vol. 1, no. 2, pp. 93-99, 2008.
[36] M. G. Backlund, J. R. Mann, V. R. Holla et al., "15-hydroxyprostaglandin dehydrogenase is down-regulated in colorectal cancer," The Journal of Biological Chemistry, vol. 280, no. 5, pp. 3217-3223, 2005.

[37] Z. M. Zaïr, J. J. Eloranta, B. Stieger, and G. A. Kullak-Ublick, "Pharmacogenetics of OATP (SLC21/SLCO), OAT and OCT (SLC22) and PEPT (SLC15) transporters in the intestine, liver and kidney," Pharmacogenomics, vol. 9, no. 5, pp. 597624, 2008.

[38] H. H. Tai, H. Cho, M. Tong, and Y. Ding, "NAD+-linked 15hydroxyprostaglandin dehydrogenase: structure and biological function," Current Pharmaceutical Design, vol. 12, no. 8, pp. 955-962, 2006.

[39] M. G. Backlund, J. R. Mann, V. R. Holla et al., "Repression of 15-hydroxyprostaglandin dehydrogenase involves histone deacetylase 2 and snail in colorectal cancer," Cancer Research, vol. 68, no. 22, pp. 9331-9337, 2008.

[40] S. J. Myung, R. M. Rerko, M. Yan et al., "15-Hydroxyprostaglandin dehydrogenase is an in vivo suppressor of colon tumorigenesis," Proceedings of the National Academy of Sciences of the United States of America, vol. 103, no. 32, pp. 12098-12102, 2006.

[41] A. Parekh, V. C. Sandulache, T. Singh et al., "Prostaglandin $\mathrm{E}_{2}$ differentially regulates contraction and structural reorganization of anchored collagen gels by human adult and fetal dermal fibroblasts," Wound Repair and Regeneration, vol. 17, no. 1, pp. 88-98, 2009.

[42] S. Miyatake, H. Manabe-Kawaguchi, K. Watanabe, S. Hori, N. Aikawa, and K. Fukuda, "Prostaglandin $\mathrm{E}_{2}$ induces hypertrophic changes and suppresses $\alpha$-skeletal actin gene expression in rat cardiomyocytes," Journal of Cardiovascular Pharmacology, vol. 50, no. 5, pp. 548-554, 2007.

[43] L. M. Crosby and C. M. Waters, "Epithelial repair mechanisms in the lung," American Journal of Physiology-Lung Cellular and Molecular Physiology, vol. 298, no. 6, pp. L715L731, 2010.

[44] B. Müller-Hübenthal, M. Azemar, D. Lorenzen et al., "Tumour biology: tumour-associated inflammation versus antitumor immunity," Anticancer Research, vol. 29, no. 11, pp. 4795-4805, 2009.

[45] J. W. Fischer and K. Schrör, "Regulation of hyaluronan synthesis by vasodilatory prostaglandins: implications for atherosclerosis," Thrombosis and Haemostasis, vol. 98, no. 2, pp. 287-295, 2007.

[46] Y. T. Konttinen, T. F. Li, M. Hukkanen, J. Ma, J. W. Xu, and I. Virtanen, "Fibroblasts biology: signals targeting the synovial fibroblast in arthritis," Arthritis Research, vol. 2, no. 5, pp. 348-355, 2000.

[47] E. S. Harris and W. J. Nelson, "VE-cadherin: at the front, center, and sides of endothelial cell organization and function," Current Opinion in Cell Biology, vol. 22, no. 5, pp. 651-658, 2010.

[48] C. M. Niessen, D. Leckband, and A. S. Yap, "Tissue organization by cadherin adhesion molecules: dynamic molecular and cellular mechanisms of morphogenetic regulation," Physiological Reviews, vol. 91, no. 2, pp. 691-731, 2011.

[49] B. Baum and M. Georgiou, "Dynamics of adherens junctions in epithelial establishment, maintenance, and remodeling," Journal of Cell Biology, vol. 192, no. 6, pp. 907-917, 2011.

[50] G. Berx and F. van Roy, "Involvement of members of the cadherin superfamily in cancer," Cold Spring Harbor Perspectives in Biology, vol. 1, no. 6, Article ID a003129, 2009. 
[51] K. J. Green, S. Getsios, S. Troyanovsky, and L. M. Godsel, "Intercellular junction assembly, dynamics, and homeostasis," Cold Spring Harbor Perspectives in Biology, vol. 2, no. 2, Article ID a000125, 2010.

[52] M. Yilmaz and G. Christofori, "Mechanisms of motility in metastasizing cells," Molecular Cancer Research, vol. 8, no. 5, pp. 629-642, 2010.

[53] S. Brouxhon, S. Kyrkanides, M. K. O’Banion et al., "Sequential down-regulation of E-cadherin with squamous cell carcinoma progression: loss of E-cadherin via a prostaglandin $\mathrm{E}_{2}$-EP2-dependent posttranslational mechanism," Cancer Research, vol. 67, no. 16, pp. 7654-7664, 2007.

[54] S. Fukuhara and N. Mochizuki, "Signaling mechanism involved in regulation of endothelial cell-cell junctions," Yakugaku Zasshi, vol. 130, no. 11, pp. 1413-1420, 2010.

[55] S. Fukuhara, A. Sakurai, H. Sano et al., "Cyclic AMP potentiates vascular endothelial cadherin-mediated cell-cell contact to enhance endothelial barrier function through an Epac-Rap1 signaling pathway," Molecular and Cellular Biology, vol. 25, no. 1, pp. 136-146, 2005.

[56] E. I. Heath, M. I. Canto, S. Piantadosi et al., "Secondary chemoprevention of Barrett's esophagus with celecoxib: results of a randomized trial," Journal of the National Cancer Institute, vol. 99, no. 7, pp. 545-557, 2007.

[57] N. R. London, K. J. Whitehead, and D. Y. Li, "Endogenous endothelial cell signaling systems maintain vascular stability," Angiogenesis, vol. 12, no. 2, pp. 149-158, 2009.

[58] T. Watanabe, K. Sato, and K. Kaibuchi, "Cadherin-mediated intercellular adhesion and signaling cascades involving small GTPases," Cold Spring Harbor Perspectives in Biology, vol. 1, no. 3, Article ID a003020, 2009.

[59] T. Nishimura and M. Takeichi, "Remodeling of the adherens junctions during morphogenesis," Current Topics in Developmental Biology, vol. 89, pp. 33-54, 2009.

[60] N. Nishimura and T. Sasaki, "Rab family small G proteins in regulation of epithelial apical junctions," Frontiers in Bioscience, vol. 14, pp. 2115-2129, 2009.

[61] M. Cavey and T. Lecuit, "Molecular bases of cell-cell junctions stability and dynamics," Cold Spring Harbor Perspectives in Biology, vol. 1, no. 5, Article ID a002998, 2009.

[62] C. D. White, M. D. Brown, and D. B. Sacks, "IQGAPs in cancer: a family of scaffold proteins underlying tumorigenesis," FEBS Letters, vol. 583, no. 12, pp. 1817-1824, 2009.

[63] D. T. Brandt and R. Grosse, "Get to grips: steering local actin dynamics with IQGAPs," EMBO Reports, vol. 8, no. 11, pp. 1019-1023, 2007.

[64] S. Ory and S. Gasman, "Rho GTPases and exocytosis: what are the molecular links?" Seminars in Cell and Developmental Biology, vol. 22, no. 1, pp. 27-32, 2011.

[65] L. Asnaghi, W. C. Vass, R. Quadri et al., "E-cadherin negatively regulates neoplastic growth in non-small cell lung cancer: role of Rho GTPases," Oncogene, vol. 29, no. 19, pp. 2760-2771, 2010.

[66] S. Cabodi, M. del Pilar Camacho-Leal, P. Di Stefano, and P. Defilippi, "Integrin signalling adaptors: not only figurants in the cancer story," Nature Reviews Cancer, vol. 10, no. 12, pp. 858-870, 2010.

[67] L. Damiano, P. Di Stefano, M. P. Camacho Leal et al., "P140Cap dual regulation of E-cadherin/EGFR cross-talk and Ras signalling in tumour cell scatter and proliferation," Oncogene, vol. 29, no. 25, pp. 3677-3690, 2010.

[68] P. Di Stefano, L. Damiano, S. Cabodi et al., "p140Cap protein suppresses tumour cell properties, regulating Csk and Src kinase activity," The EMBO Journal, vol. 26, no. 12, pp. 28432855, 2007.

[69] P. J. Phillips-Mason, H. Kaur, S. M. Burden-Gulley, S. E.L. Craig, and S. M. Brady-Kalnay, "Identification of phospholipase $\mathrm{C}$ gammal as a protein tyrosine phosphatase $\mathrm{mu}$ substrate that regulates cell migration," Journal of Cellular Biochemistry, vol. 112, no. 1, pp. 39-48, 2011.

[70] S. A. Oblander and S. M. Brady-Kalnay, "Distinct PTPmuassociated signaling molecules differentially regulate neurite outgrowth on E-, N-, and R-cadherin," Molecular and Cellular Neuroscience, vol. 44, no. 1, pp. 78-93, 2010.

[71] Y. Takai, J. Miyoshi, W. Ikeda, and H. Ogita, "Nectins and nectin-like molecules: roles in contact inhibition of cell movement and proliferation," Nature Reviews Molecular Cell Biology, vol. 9, no. 8, pp. 603-615, 2008.

[72] Y. Takai, W. Ikeda, H. Ogita, and Y. Rikitake, "The immunoglobulin-like cell adhesion molecule nectin and its associated protein afadin," Annual Review of Cell and Developmental Biology, vol. 24, pp. 309-342, 2008.

[73] A. Wells, Y. L. Chao, J. Grahovac, Q. Wu, and D. A. Lauffenburger, "Epithelial and mesenchymal phenotypic switchings modulate cell motility in metastasis," Frontiers in Bioscience, vol. 16, no. 3, pp. 815-837, 2011.

[74] L. Orlichenko, S. G. Weller, H. Cao et al., "Caveolae mediate growth factor-induced disassembly of adherens junctions to support tumor cell dissociation," Molecular Biology of the Cell, vol. 20, no. 19, pp. 4140-4152, 2009.

[75] S. Kon, K. Tanabe, T. Watanabe, H. Sabe, and M. Satake, "Clathrin dependent endocytosis of E-cadherin is regulated by the Arf6GAP isoform SMAP1," Experimental Cell Research, vol. 314, no. 7, pp. 1415-1428, 2008.

[76] Z. Lu, S. Ghosh, Z. Wang, and T. Hunter, "Downregulation of caveolin-1 function by EGF leads to the loss of E-cadherin, increased transcriptional activity of $\beta$-catenin, and enhanced tumor cell invasion," Cancer Cell, vol. 4, no. 6, pp. 499-515, 2003.

[77] M. Shipitsin and L. A. Feig, "RalA but not RalB enhances polarized delivery of membrane proteins to the basolateral surface of epithelial cells," Molecular and Cellular Biology, vol. 24, no. 13, pp. 5746-5756, 2004.

[78] C. Huang, "Roles of E3 ubiquitin ligases in cell adhesion and migration," Cell Adhesion and Migration, vol. 4, no. 1, pp. 10$18,2010$.

[79] B. Boettner and L. Van Aelst, "Control of cell adhesion dynamics by Rap1 signaling," Current Opinion in Cell Biology, vol. 21, no. 5, pp. 684-693, 2009.

[80] S. F. Retta, F. Balzac, and M. Avolio, "Rap1: a turnabout for the crosstalk between cadherins and integrins," European Journal of Cell Biology, vol. 85, no. 3-4, pp. 283-293, 2006.

[81] J. Gavard, "Breaking the VE-cadherin bonds," FEBS Letters, vol. 583, no. 1, pp. 1-6, 2009.

[82] D. Vestweber, M. Winderlich, G. Cagna, and A. F. Nottebaum, "Cell adhesion dynamics at endothelial junctions: VEcadherin as a major player," Trends in Cell Biology, vol. 19, no. 1, pp. 8-15, 2009.

[83] L. Cheng and M. D. Lai, "Aberrant crypt foci as microscopic precursors of colorectal cancer," World Journal of Gastroenterology, vol. 9, no. 12, pp. 2642-2649, 2003.

[84] T. W. Moody, C. Switzer, W. Santana-Flores et al., "Dithiolethione modified valproate and diclofenac increase Ecadherin expression and decrease proliferation of non-small cell lung cancer cells," Lung Cancer, vol. 68, no. 2, pp. 154160, 2010 . 
[85] T. J. Jang, W. H. Cha, and K. S. Lee, "Reciprocal correlation between the expression of cyclooxygenase-2 and E-cadherin in human bladder transitional cell carcinomas," Virchows Archiv, vol. 457, no. 3, pp. 319-328, 2010.

[86] S. A. Mani, W. Guo, M. J. Liao et al., "The epithelialmesenchymal transition generates cells with properties of stem cells," Cell, vol. 133, no. 4, pp. 704-715, 2008.

[87] T. J. Jang, K. H. Jeon, and K. H. Jung, "Cyclooxygenase2 expression is related to the epithelial-to-mesenchymal transition in human colon cancers," Yonsei Medical Journal, vol. 50, no. 6, pp. 818-824, 2009.

[88] M. Tsujii and R. N. DuBois, "Alterations in cellular adhesion and apoptosis in epithelial cells overexpressing prostaglandin endoperoxide synthase 2," Cell, vol. 83, no. 3, pp. 493-501, 1995.

[89] J. Ju, B. Nolan, M. Cheh et al., "Voluntary exercise inhibits intestinal tumorigenesis in $A p c^{\mathrm{Min} /+}$ mice and azoxymethane/dextran sulfate sodium-treated mice," BMC Cancer, vol. 8, article 316, 2008.

[90] C. K. Speirs, K. K. Jernigan, S. H. Kim et al., "Prostaglandin $\mathrm{G} \beta \gamma$ signaling stimulates gastrulation movements by limiting cell adhesion through Snaila stabilization," Development, vol. 137, no. 8, pp. 1327-1337, 2010.

[91] F. Nuñez, S. Bravo, F. Cruzat, M. Montecino, and G. V. de Ferrari, "Wnt $/ \beta$-catenin signaling enhances cyclooxygenase2 (COX2) transcriptional activity in gastric cancer cells," PLoS ONE, vol. 6, no. 4, Article ID e18562, 2011.

[92] D. A. Rodriguez, J. C. Tapia, J. G. Fernandez et al., "Caveolin-1-mediated suppression of cyclooxygenase-2 via a $\beta$-catenin-Tcf/Lef-dependent transcriptional mechanism reduced prostaglandin $\mathrm{E}_{2}$ production and survivin expression," Molecular Biology of the Cell, vol. 20, no. 8, pp. 2297-2310, 2009.

[93] R. G. Rowe and S. J. Weiss, "Breaching the basement membrane: who, when and how?" Trends in Cell Biology, vol. 18, no. 11, pp. 560-574, 2008.

[94] A. Pozzi and R. Zent, "Regulation of endothelial cell functions by basement membrane- and arachidonic acid-derived products," Wiley Interdisciplinary Reviews: Systems Biology and Medicine, vol. 1, no. 2, pp. 254-272, 2009.

[95] J. K. Kundu and Y. J. Surh, "Inflammation: gearing the journey to cancer," Mutation Research, vol. 659, no. 1-2, pp. 15-30, 2008.

[96] B. Eyden, K. Yamazaki, L. P. Menasce, A. Charchanti, and N. J. Agnantis, "Basement-membrane-related peri-vascular matrices not organised as a basal lamina: distribution in malignant tumours and benign lesions," Journal of Submicroscopic Cytology and Pathology, vol. 32, no. 4, pp. 515-523, 2000.

[97] M. J. Evans, M. V. Fanucchi, C. G. Plopper, and D. M. Hyde, "Postnatal development of the lamina reticularis in primate airways," Anatomical Record, vol. 293, no. 6, pp. 947-954, 2010.

[98] A. H. Melcher and J. Chan, "Continuity of electron histochemically demonstrable substances in the basal lamina, the ground substance of the connective tissue and the intercellular spaces of epithelial cells of rat gingiva," Journal of Anatomy, vol. 127, part 2, pp. 261-271, 1978.

[99] M. J. Snodgrass, "Ultrastructural distinction between reticular and collagenous fibers with an ammoniacal silver stain," Anatomical Record, vol. 187, no. 2, pp. 191-205, 1977.

[100] T. Soma, K. Nishida, M. Yamato et al., "Histological evaluation of mechanical epithelial separation in epithelial laser in situ keratomileusis," Journal of Cataract and Refractive Surgery, vol. 35, no. 7, pp. 1251-1259, 2009.

[101] J. R. McMillan, M. Akiyama, and H. Shimizu, "Ultrastructural orientation of laminin 5 in the epidermal basement membrane: an updated model for basement membrane organization," Journal of Histochemistry and Cytochemistry, vol. 51, no. 10, pp. 1299-1306, 2003.

[102] G. Westergren-Thorsson, K. Larsen, K. Nihlberg et al., "Pathological airway remodelling in inflammation," The Clinical Respiratory Journal, vol. 4, supplement 1, pp. 1-8, 2010.

[103] O. A. Sveinsson, K. B. Orvar, S. Birgisson, and J. G. Jonasson, "Microscopic colitis-review," Laeknabladid, vol. 94, no. 5, pp. 363-370, 2008.

[104] E. Di Tomaso, D. Capen, A. Haskell et al., "Mosaic tumor vessels: cellular basis and ultrastructure of focal regions lacking endothelial cell markers," Cancer Research, vol. 65, no. 13, pp. 5740-5749, 2005.

[105] B. Eyden and M. Tzaphlidou, "Structural variations of collagen in normal and pathological tissues: role of electron microscopy," Micron, vol. 32, no. 3, pp. 287-300, 2001.

[106] I. D. Campbell and M. J. Humphries, "Integrin structure, activation, and interactions," Cold Spring Harbor Perspectives in Biology, vol. 3, no. 3, 2011.

[107] M. Barczyk, S. Carracedo, and D. Gullberg, "Integrins," Cell and Tissue Research, vol. 339, no. 1, pp. 269-280, 2010.

[108] R. O. Hynes, "Integrins: a family of cell surface receptors," Cell, vol. 48, no. 4, pp. 549-554, 1987.

[109] E. Ruoslahti and M. D. Pierschbacher, "New perspectives in cell adhesion: RGD and integrins," Science, vol. 238, no. 4826, pp. 491-497, 1987.

[110] R. O. Hynes, "The extracellular matrix: not just pretty fibrils," Science, vol. 326, no. 5957, pp. 1216-1219, 2009.

[111] B. H. Luo, C. V. Carman, and T. A. Springer, "Structural basis of integrin regulation and signaling," Annual Review of Immunology, vol. 25, pp. 619-647, 2007.

[112] S. J. Shattil, C. Kim, and M. H. Ginsberg, "The final steps of integrin activation: the end game," Nature Reviews Molecular Cell Biology, vol. 11, no. 4, pp. 288-300, 2010.

[113] J. L. Baneres, F. Roquet, M. Green, H. LeCalvez, and J. Parello, "The cation-binding domain from the alpha subunit of integrin alpha5 beta1 is a minimal domain for fibronectin recognition," The Journal of Biological Chemistry, vol. 273, no. 38, pp. 24744-24753, 1998.

[114] J. Takagi, K. Strokovich, T. A. Springer, and T. Walz, "Structure of integrin $\alpha 5 \beta 1$ in complex with fibronectin," The EMBO Journal, vol. 22, no. 18, pp. 4607-4615, 2003.

[115] J. Takagi, B. M. Petre, T. Walz, and T. A. Springer, "Global conformational earrangements in integrin extracellular domains in outside-in and inside-out signaling," Cell, vol. 110, no. 5, pp. 599-611, 2002.

[116] N. Nishida, C. Xie, M. Shimaoka, Y. Cheng, T. Walz, and T. A. Springer, "Activation of leukocyte $\beta 2$ integrins by conversion from bent to extended conformations," Immunity, vol. 25, no. 4, pp. 583-594, 2006.

[117] S. Ben-Horin and I. Bank, "The role of very late antigen-1 in immune-mediated inflammation," Clinical Immunology, vol. 113, no. 2, pp. 119-129, 2004.

[118] E. J. Müller, L. Williamson, C. Kolly, and M. M. Suter, “Outside-in signaling through integrins and cadherins: a central mechanism to control epidermal growth and differentiation?" Journal of Investigative Dermatology, vol. 128, no. 3, pp. 501-516, 2008. 
[119] N. J. Anthis and I. D. Campbell, "The tail of integrin activation," Trends in Biochemical Sciences, vol. 36, no. 4, pp. 191-198, 2011.

[120] M. Moser, K. R. Legate, R. Zent, and R. Fässler, "The tail of integrins, talin, and kindlins," Science, vol. 324, no. 5929, pp. 895-899, 2009.

[121] M. A. Schwartz, "Integrins and extracellular matrix in mechanotransduction," Cold Spring Harbor Perspectives in Biology, vol. 2, no. 12, Article ID a005066, 2010.

[122] I. Patla, T. Volberg, N. Elad et al., "Dissecting the molecular architecture of integrin adhesion sites by cryo-electron tomography," Nature Cell Biology, vol. 12, no. 9, pp. 909-915, 2010.

[123] B. Geiger, J. P. Spatz, and A. D. Bershadsky, "Environmental sensing through focal adhesions," Nature Reviews Molecular Cell Biology, vol. 10, no. 1, pp. 21-33, 2009.

[124] J. P. Spatz and B. Geiger, "Molecular engineering of cellular environments: cell adhesion to nano-digital surfaces," Methods in Cell Biology, vol. 83, pp. 89-111, 2007.

[125] E. A. Cavalcanti-Adam, T. Volberg, A. Micoulet, H. Kessler, B. Geiger, and J. P. Spatz, "Cell spreading and focal adhesion dynamics are regulated by spacing of integrin ligands," Biophysical Journal, vol. 92, no. 8, pp. 2964-2974, 2007.

[126] L. R. Rohrschneider, "Adhesion plaques of Rous sarcoma virus-transformed cells contain the src gene product," Proceedings of the National Academy of Sciences of the United States of America, vol. 77, no. 6, pp. 3514-3518, 1980.

[127] J. L. Guan, "Integrin signaling through FAK in the regulation of mammary stem cells and breast cancer," IUBMB Life, vol. 62, no. 4, pp. 268-276, 2010.

[128] J. Zhao and J. L. Guan, "Signal transduction by focal adhesion kinase in cancer," Cancer and Metastasis Reviews, vol. 28, no. 1-2, pp. 35-49, 2009.

[129] M. D. Schaller, C. A. Borgman, B. S. Cobb, R. R. Vines, A. B. Reynolds, and J. T. Parsons, "pp125(FAK), a structurally distinctive protein-tyrosine kinase associated with focal adhesions," Proceedings of the National Academy of Sciences of the United States of America, vol. 89, no. 11, pp. 5192-5196, 1992.

[130] M. D. Schaller, J. D. Hildebrand, J. D. Shannon, J. W. Fox, R. R. Vines, and J. T. Parsons, "Autophosphorylation of the focal adhesion kinase, pp125(FAK), directs SH2- dependent binding of pp60(src)," Molecular and Cellular Biology, vol. 14, no. 3, pp. 1680-1688, 1994.

[131] J. E. Hall, W. Fu, and M. D. Schaller, "Focal adhesion kinase: exploring FAK structure to gain insight into function," International Review of Cell and Molecular Biology, vol. 288, pp. 185-225, 2011.

[132] M. D. Schaller, "Cellular functions of FAK kinases: insight into molecular mechanisms and novel functions," Journal of Cell Science, vol. 123, part 7, pp. 1007-1013, 2010.

[133] M. D. Schaller and J. T. Parsons, "pp125(FAK)-dependent tyrosine phosphorylation of paxillin creates a high- affinity binding site for Crk," Molecular and Cellular Biology, vol. 15, no. 5, pp. 2635-2645, 1995.

[134] C. E. Turner, J. R. Glenney Jr., and K. Burridge, "Paxillin: a new vinculin-binding protein present in focal adhesions," Journal of Cell Biology, vol. 111, no. 3, pp. 1059-1068, 1990.

[135] G. M. O’Neill, S. Seo, I. G. Serebriiskii, S. R. Lessin, and E. A. Golemis, "A new central scaffold for metastasis: parsing HEF1/Cas-L/NEDD9,” Cancer Research, vol. 67, no. 19, pp. 8975-8979, 2007.

[136] N. Tikhmyanova, J. L. Little, and E. A. Golemis, "CAS proteins in normal and pathological cell growth control,"
Cellular and Molecular Life Sciences, vol. 67, no. 7, pp. 10251048, 2010.

[137] S. R. Frank and S. H. Hansen, "The PIX-GIT complex: a G protein signaling cassette in control of cell shape," Seminars in Cell and Developmental Biology, vol. 19, no. 3, pp. 234-244, 2008.

[138] N. Volkmann, K. J. Amann, S. Stoilova-McPhie et al., "Structure of arp2/3 complex in its activated state and in actin filament branch junctions," Science, vol. 293, no. 5539, pp. 2456-2459, 2001.

[139] J. L. Bos, H. Rehmann, and A. Wittinghofer, "GEFs and GAPs: critical elements in the control of small G proteins," Cell, vol. 129, no. 5, pp. 865-877, 2007.

[140] J. D. Hildebrand, J. M. Taylor, and J. T. Parsons, "An SH3 domain-containing GTPase-activating protein for Rho and Cdc42 associates with focal adhesion kinase," Molecular and Cellular Biology, vol. 16, no. 6, pp. 3169-3178, 1996.

[141] A. Tomar, S. T. Lim, Y. Lim, and D. D. Schlaepfer, "A FAKp120RasGAP-p190RhoGAP complex regulates polarity in migrating cells," Journal of Cell Science, vol. 122, part 11, pp. 1852-1862, 2009.

[142] M. P. Iwanicki, T. Vomastek, R. W. Tilghman et al., "FAK, PDZ-RhoGEF and ROCKII cooperate to regulate adhesion movement and trailing-edge retraction in fibroblasts," Journal of Cell Science, vol. 121, part 6, no. 6, pp. 895-905, 2008.

[143] S. W. Luo, C. Zhang, B. Zhang et al., "Regulation of heterochromatin remodelling and myogenin expression during muscle differentiation by FAK interaction with MBD2," The EMBO Journal, vol. 28, no. 17, pp. 2568-2582, 2009.

[144] H. L. Glenn and B. S. Jacobson, "Cyclooxygenase and cAMPdependent protein kinase reorganize the actin cytoskeleton for motility in HeLa cells," Cell Motility and the Cytoskeleton, vol. 55, no. 4, pp. 265-277, 2003.

[145] M. K. Cho, Y. H. Cho, G. H. Lee, and S. G. Kim, "Induction of cyclooxygenase- 2 by bovine type I collagen in macrophages via C/EBP and CREB activation by multiple cell signaling pathways," Biochemical Pharmacology, vol. 67, no. 12, pp. 2239-2250, 2004.

[146] S. M. Ponik and F. M. Pavalko, "Formation of focal adhesions on fibronectin promotes fluid shear stress induction of COX2 and $\mathrm{PGE}_{2}$ release in MC3T3-E1 osteoblasts," Journal of Applied Physiology, vol. 97, no. 1, pp. 135-142, 2004.

[147] E. Takai, R. Landesberg, R. W. Katz, C. T. Hung, and X. E. Guo, "Substrate modulation of osteoblast adhesion strength, focal adhesion kinase activation, and responsiveness to mechanical stimuli," MCB Molecular and Cellular Biomechanics, vol. 3, no. 1, pp. 1-12, 2006.

[148] S. R. L. Young, R. Gerard-O'Riley, J. B. Kim, and F. M. Pavalko, "Focal adhesion kinase is important for fluid shear stress-induced mechanotransduction in osteoblasts," Journal of Bone and Mineral Research, vol. 24, no. 3, pp. 411-424, 2009.

[149] S. H. Kim, D. Xia, S. W. Kim, V. Holla, D. G. Menter, and R. N. DuBois, "Human enhancer of filamentation 1 is a mediator of hypoxia-inducible factor- $1 \alpha$-mediated migration in colorectal carcinoma cells," Cancer Research, vol. 70, no. 10, pp. 4054-4063, 2010.

[150] K. L. Pierce, H. Fujino, D. Srinivasan, and J. W. Regan, "Activation of FP prostanoid receptor isoforms leads to rho-mediated changes in cell morphology and in the cell cytoskeleton," The Journal of Biological Chemistry, vol. 274, no. 50, pp. 35944-35949, 1999.

[151] H. Fujino, K. L. Pierce, D. Srinivasan et al., "Delayed reversal of shape change in cells expressing FPB prostanoid receptors: 
possible role of receptor resensitization," The Journal of Biological Chemistry, vol. 275, no. 38, pp. 29907-29914, 2000.

[152] K. J. Sales, S. C. Boddy, and H. N. Jabbour, "F-prostanoid receptor alters adhesion, morphology and migration of endometrial adenocarcinoma cells," Oncogene, vol. 27, no. 17, pp. 2466-2477, 2008.

[153] X. M. Bai, W. Zhang, N. B. Liu et al., "Focal adhesion kinase: important to prostaglandin $\mathrm{E}_{2}$-mediated adhesion, migration and invasion in hepatocellular carcinoma cells," Oncology Reports, vol. 21, no. 1, pp. 129-136, 2009.

[154] A. Meves, C. Stremmel, K. Gottschalk, and R. Fässler, “The Kindlin protein family: new members to the club of focal adhesion proteins," Trends in Cell Biology, vol. 19, no. 10, pp. 504-513, 2009.

[155] P. Hernández-Varas, G. P. Coló, R. A. Bartolomé et al., "Rap1GTP-interacting adaptor molecule (RIAM) protein controls invasion and growth of melanoma cells," The Journal of Biological Chemistry, vol. 286, no. 21, pp. 18492-18504, 2011.

[156] M. Tsujii, S. Kawano, S. Tsuji, H. Sawaoka, M. Hori, and R. N. DuBois, "Cyclooxygenase regulates angiogenesis induced by colon cancer cells," Cell, vol. 93, no. 5, pp. 705-716, 1998.

[157] X. Norel, "Prostanoid receptors in the human vascular wall," TheScientificWorldJournal, vol. 7, pp. 1359-1374, 2007.

[158] K. Schror, "Prostaglandins, other eicosanoids and endothelial cells," Basic Research in Cardiology, vol. 80, no. 5, pp. 502514, 1985.

[159] D. Wang, H. Wang, J. Brown et al., "CXCL1 induced by prostaglandin $\mathrm{E}_{2}$ promotes angiogenesis in colorectal cancer," Journal of Experimental Medicine, vol. 203, no. 4, pp. 941-951, 2006.

[160] F. G. Buchanan, W. Chang, H. Sheng, J. Shao, J. D. Morrow, and R. N. Dubois, "Up-regulation of the enzymes involved in prostacyclin synthesis via Ras induces vascular endothelial growth factor," Gastroenterology, vol. 127, no. 5, pp. 13911400, 2004.

[161] R. A. Gupta, L. V. Tejada, B. J. Tong et al., "Cyclooxygenase1 is overexpressed and promotes angiogenic growth factor production in ovarian cancer," Cancer Research, vol. 63, no. 5, pp. 906-911, 2003.

[162] C. S. Williams, M. Tsujii, J. Reese, S. K. Dey, and R. N. DuBois, "Host cyclooxygenase-2 modulates carcinoma growth," Journal of Clinical Investigation, vol. 105, no. 11, pp. 1589-1594, 2000.

[163] M. G. Cattaneo, S. Pola, V. Dehò, A. M. Sanguini, and L. M. Vicentini, "Alprostadil suppresses angiogenesis in vitro and in vivo in the murine Matrigel plug assay," British Journal of Pharmacology, vol. 138, no. 2, pp. 377-385, 2003.

[164] O. Dormond and C. Rüegg, "Regulation of endothelial cell integrin function and angiogenesis by COX-2, cAMP and protein kinase A," Thrombosis and Haemostasis, vol. 90, no. 4, pp. 577-585, 2003.

[165] O. Dormond, M. Bezzi, A. Mariotti, and C. Rüegg, "Prostaglandin $\mathrm{E}_{2}$ promotes integrin $\alpha_{\mathrm{V}} \beta_{3}$-dependent endothelial cell adhesion, Rac-activation, and spreading through cAMP/PKA-dependent signaling," The Journal of Biological Chemistry, vol. 277, no. 48, pp. 45838-45846, 2002.

[166] C. Rüegg, O. Dormond, and A. Mariotti, "Endothelial cell integrins and COX-2: mediators and therapeutic targets of tumor angiogenesis," Biochimica et Biophysica Acta, vol. 1654, no. 1, pp. 51-67, 2004.

[167] O. Dormond, A. Foletti, C. Paroz, and C. Rüegg, "NSAIDS inhibit $\alpha_{\mathrm{V}} \beta_{3}$ integrin-mediated and Cdc42/Rac-dependent endothelial-cell spreading, migration and angiogenesis," Nature Medicine, vol. 7, no. 9, pp. 1041-1047, 2001.

[168] K. Mitchell, K. B. Svenson, W. M. Longmate et al., "Suppression of integrin $\alpha 3 \beta 1$ in breast cancer cells reduces cyclooxygenase-2 gene expression and inhibits tumorigenesis, invasion, and cross-talk to endothelial cells," Cancer Research, vol. 70, no. 15, pp. 6359-6367, 2010.

[169] R. Silva, G. D’Amico, K. M. Hodivala-Dilke, and L. E. Reynolds, "Integrins: the keys to unlocking angiogenesis," Arteriosclerosis, Thrombosis, and Vascular Biology, vol. 28, no. 10, pp. 1703-1713, 2008.

[170] F. G. Giancotti, "Targeting integrin $\beta 4$ for cancer and antiangiogenic therapy," Trends in Pharmacological Sciences, vol. 28, no. 10, pp. 506-511, 2007.

[171] T. D. Abair, N. Bulus, C. Borza, M. Sundaramoorthy, R. Zent, and A. Pozzi, "Functional analysis of the cytoplasmic domain of the integrin alphal subunit in endothelial cells," Blood, vol. 112, no. 8, pp. 3242-3254, 2008.

[172] M. C. Whelan and D. R. Senger, "Collagen I initiates endothelial cell morphogenesis by inducing actin polymerization through suppression of cyclic AMP and protein kinase A," The Journal of Biological Chemistry, vol. 278, no. 1, pp. 327334, 2003.

[173] G. Alghisi and C. Rüegg, "Vascular integrins in tumor angiogenesis: mediators and therapeutic targets," Endothelium, vol. 13, no. 2, pp. 113-135, 2006.

[174] Z. Zhang, N. E. Ramirez, T. E. Yankeelov et al., " $\alpha 2 \beta 1$ integrin expression in the tumor microenvironment enhances tumor angiogenesis in a tumor cell-specific manner," Blood, vol. 111, no. 4, pp. 1980-1988, 2008.

[175] M. C. Zweers, J. M. Davidson, A. Pozzi et al., "Integrin $\alpha 2 \beta 1$ is required for regulation of murine wound angiogenesis but is dispensable for reepithelialization," Journal of Investigative Dermatology, vol. 127, no. 2, pp. 467-478, 2007.

[176] H. Sheng, J. Shao, M. K. Washington, and R. N. DuBois, "Prostaglandin $\mathrm{E}_{2}$ increases growth and motility of colorectal carcinoma cells," The Journal of Biological Chemistry, vol. 276, no. 21, pp. 18075-18081, 2001.

[177] R. Massoumi, C. K. Nielsen, D. Azemovic, and A. Sjölander, "Leukotriene D4-induced adhesion of Caco-2 cells is mediated by prostaglandin $\mathrm{E}_{2}$ and upregulation of $\alpha 2 \beta 1$-integrin," Experimental Cell Research, vol. 289, no. 2, pp. 342-351, 2003.

[178] K. Yazawa, N. H. Tsuno, J. Kitayama et al., "Selective inhibition of cyclooxygenase-2 inhibits colon cancer cell adhesion to extracellular matrix by decreased expression of ß1 integrin," Cancer Science, vol. 96, no. 2, pp. 93-99, 2005.

[179] S. Z. Zhang and A. M. Fulton, "Modulation of integrinlaminin receptor function on mammary tumor cells by prostaglandin $\mathrm{E}_{2}$ receptor antagonism," Cancer Letters, vol. 85, no. 2, pp. 233-238, 1994.

[180] S. Han, N. Sidell, S. Roser-Page, and J. Roman, "Fibronectin stimulates human lung carcinoma cell growth by inducing cyclooxygenase-2 (COX-2) expression," International Journal of Cancer, vol. 111, no. 3, pp. 322-331, 2004.

[181] J. K. L. Colby, R. D. Klein, M. J. McArthur et al., "Progressive metaplastic and dysplastic changes in mouse pancreas induced by cyclooxygenase-2 overexpression," Neoplasia, vol. 10, no. 8, pp. 782-796, 2008.

[182] H. Chopra, J. Timar, Y. Q. Chen et al., "The lipoxygenase metabolite 12(S)-hete induces a cytoskeleton-dependent increase in surface expression of integrin $\alpha(\mathrm{IIb}) \beta 3$ on melanoma cells," International Journal of Cancer, vol. 49, no. 5, pp. 774-786, 1991. 
[183] K. V. Honn, I. M. Grossi, L. A. Fitzgerald, L. A. Umbarger, C. A. Diglio, and J. D. Taylor, "Lipoxygenase products regulate IRGpIIb/IIIa receptor mediated adhesion of tumor cells to endothelial cells, subendothelial matrix and fibronectin," Proceedings of the Society for Experimental Biology and Medicine, vol. 189, no. 1, pp. 130-135, 1988.

[184] L. Kular, J. Pakradouni, P. Kitabgi, M. Laurent, and C. Martinerie, "The CCN family: a new class of inflammation modulators?" Biochimie, vol. 93, no. 3, pp. 377-388, 2010.

[185] T. P. O’Brien, G. P. Yang, L. Sanders, and L. F. Lau, "Expression of cyr61, a growth factor-inducible immediate-early gene," Molecular and Cellular Biology, vol. 10, no. 7, pp. 35693577, 1990.

[186] D. M. Bradham, A. Igarashi, R. L. Potter, and G. R. Grotendorst, "Connective tissue growth factor: a cysteine-rich mitogen secreted by human vascular endothelial cells is related to the SRC-induced immediate early gene product CEF10," Journal of Cell Biology, vol. 114, no. 6, pp. 1285-1294, 1991.

[187] V. Joliot, C. Martinerie, G. Dambrine et al., "Proviral rearrangements and overexpression of a new cellular gene (nov) in myeloblastosis-associated virus type 1-induced nephroblastomas," Molecular and Cellular Biology, vol. 12, no. 1, pp. 10-21, 1992.

[188] D. Pennica, T. A. Swanson, J. W. Welsh et al., "WISP genes are members of the connective tissue growth factor family that are up-regulated in Wnt-1-transformed cells and aberrantly expressed in human colon tumors," Proceedings of the National Academy of Sciences of the United States of America, vol. 95, no. 25, pp. 14717-14722, 1998.

[189] M. Ono, "Molecular links between tumor angiogenesis and inflammation: inflammatory stimuli of macrophages and cancer cells as targets for therapeutic strategy," Cancer Science, vol. 99, no. 8, pp. 1501-1506, 2008.

[190] J. R. Couchman, "Transmembrane signaling proteoglycans," Annual Review of Cell and Developmental Biology, vol. 26, pp. 89-114, 2010.

[191] J. L. Dreyfuss, C. V. Regatieri, T. R. Jarrouge, R. P. Cavalheiro, L. O. Sampaio, and H. B. Nader, "Heparan sulfate proteoglycans: structure, protein interactions and cell signaling," Anais da Academia Brasileira de Ciencias, vol. 81, no. 3, pp. 409429, 2009.

[192] R. V. Iozzo and R. D. Sanderson, "Proteoglycans in cancer biology, tumour microenvironment and angiogenesis," Journal of Cellular and Molecular Medicine, vol. 15, no. 5, pp. 1013-1031, 2011.

[193] C. Kirn-Safran, M. C. Farach-Carson, and D. D. Carson, "Multifunctionality of extracellular and cell surface heparan sulfate proteoglycans," Cellular and Molecular Life Sciences, vol. 66, no. 21, pp. 3421-3434, 2009.

[194] M. C. Farach-Carson and D. D. Carson, "Perlecan-a multifunctional extracellular proteoglycan scaffold," Glycobiology, vol. 17, no. 9, pp. 897-905, 2007.

[195] S. Cattaruzza and R. Perris, "Proteoglycan control of cell movement during wound healing and cancer spreading," Matrix Biology, vol. 24, no. 6, pp. 400-417, 2005.

[196] S. -H. Kim, J. Turnbull, and S. Guimond, "Extracellular matrix and cell signalling: the dynamic cooperation of integrin, proteoglycan and growth factor receptor," Journal of Endocrinology, vol. 209, no. 2, pp. 139-151, 2011.

[197] U. Barash, V. Cohen-Kaplan, I. Dowek, R. D. Sanderson, N. Ilan, and I. Vlodavsky, "Proteoglycans in health and disease: new concepts for heparanase function in tumor progression and metastasis," FEBS Journal, vol. 277, no. 19, pp. 38903903, 2010

[198] H. Yoshino, K. Takahashi, S. Monzen, and I. Kashiwakura, "Proteoglycans regulate the chemotaxis of dendritic cells derived from human peripheral blood monocytes," Biological and Pharmaceutical Bulletin, vol. 33, no. 6, pp. 938-944, 2010.

[199] H. Katoh, K. Hosono, Y. Ito et al., "COX-2 and prostaglandin EP3/EP4 signaling regulate the tumor stromal proangiogenic microenvironment via CXCL12-CXCR4 chemokine systems," The American Journal of Pathology, vol. 176, no. 3, pp. 1469-1483, 2010.

[200] J. R. Prosperi, S. R. Mallery, K. A. Kigerl, A. A. Erfurt, and F. M. Robertson, "Invasive and angiogenic phenotype of MCF7 human breast tumor cells expressing human cyclooxygenase-2," Prostaglandins and Other Lipid Mediators, vol. 73, no. 3-4, pp. 249-264, 2004.

[201] C. W. Ko, B. Bhandari, J. Yee, W. C. Terhune, R. Maldonado, and B. S. Kasinath, "Cyclic AMP regulates basement membrane heparan sulfate proteoglycan, perlecan, metabolism in rat glomerular epithelial cells," Molecular and Cellular Biochemistry, vol. 162, no. 1, pp. 65-73, 1996.

[202] D. Aviezer, D. Hecht, M. Safran, M. Elsinger, G. David, and A. Yayon, "Perlecan, basal lamina proteoglycan, promotes basic fibroblast growth factor-receptor binding, mitogenesis, and angiogenesis," Cell, vol. 79, no. 6, pp. 1005-1013, 1994.

[203] B. Sharma, M. Handler, I. Eichstetter, J. M. Whitelock, M. A. Nugent, and R. V. Iozzo, "Antisense targeting of perlecan blocks tumor growth and angiogenesis in vivo," Journal of Clinical Investigation, vol. 102, no. 8, pp. 1599-1608, 1998.

[204] M. Yáñez-Mó, O. Barreiro, M. Gordon-Alonso, M. SalaValdés, and F. Sánchez-Madrid, "Tetraspanin-enriched microdomains: a functional unit in cell plasma membranes," Trends in Cell Biology, vol. 19, no. 9, pp. 434-446, 2009.

[205] H. -X. Wang, Q. Li, C. Sharma, K. Knoblich, and M. E. Hemler, "Tetraspanin protein contributions to cancer," Biochemical Society Transactions, vol. 39, no. 2, pp. 547-552, 2011.

[206] S. Veenbergen and A. B. van Spriel, "Tetraspanins in the immune response against cancer," Immunology Letters, vol. 138, no. 2, pp. 129-136, 2011.

[207] E. Rubinstein, “The complexity of tetraspanins," Biochemical Society Transactions, vol. 39, no. 2, pp. 501-505, 2011.

[208] M. M. Richardson, L. K. Jennings, and X. A. Zhang, "Tetraspanins and tumor progression," Clinical and Experimental Metastasis, vol. 28, no. 3, pp. 261-270, 2011.

[209] E. L. Jones, M. C. Demaria, and M. D. Wright, “Tetraspanins in cellular immunity," Biochemical Society Transactions, vol. 39, no. 2, pp. 506-511, 2011.

[210] S. Lee, Y.-A. Song, Y.-L. Park et al., "Expression of KITENIN in human colorectal cancer and its relation to tumor behavior and progression," Pathology International, vol. 61, no. 4, pp. 210-220, 2011.

[211] M. Zöller, "Tetraspanins: push and pull in suppressing and promoting metastasis," Nature Reviews Cancer, vol. 9, no. 1, pp. 40-55, 2009.

[212] J.-F. Haeuw, L. Goetsch, C. Bailly, and N. Corvaia, "Tetraspanin CD151 as a target for antibody-based cancer immunotherapy," Biochemical Society Transactions, vol. 39, no. 2, pp. 553-558, 2011.

[213] T. V. Kolesnikova, A. R. Kazarov, M. E. Lemieux et al., "Glioblastoma inhibition by cell surface immunoglobulin 
protein EWI-2, in vitro and in vivo," Neoplasia, vol. 11, no. 1, pp. 77-86, 74p following 86, 2009.

[214] T. V. Kolesnikova, C. S. Stipp, R. M. Rao, W. S. Lane, F. W. Luscinskas, and M. E. Hemler, "EWI-2 modulates lymphocyte integrin $\alpha 4 \beta 1$ functions," Blood, vol. 103, no. 8, pp. 3013-3019, 2004.

[215] D. Powner, P. M. Kopp, S. J. Monkley, D. R. Critchley, and F. Berditchevski, "Tetraspanin CD9 in cell migration," Biochemical Society Transactions, vol. 39, no. 2, pp. 563-567, 2011.

[216] S. B. Lee, A. Schramme, K. Doberstein et al., "ADAM10 is upregulated in melanoma metastasis compared with primary melanoma," Journal of Investigative Dermatology, vol. 130, no. 3, pp. 763-773, 2010.

[217] D. Xu, C. Sharma, and M. E. Hemler, "Tetraspanin 12 regulates ADAM10-dependent cleavage of amyloid precursor protein," FASEB Journal, vol. 23, no. 11, pp. 3674-3681, 2009.

[218] H. S. Ryu, Y. L. Park, S. J. Park et al., "KITENIN is associated with tumor progression in human gastric cancer," Anticancer Research, vol. 30, no. 9, pp. 3479-3486, 2010.

[219] C. Claas, J. Wahl, D. J. Orlicky et al., "The tetraspanin D6.1A and its molecular partners on rat carcinoma cells," Biochemical Journal, vol. 389, part 1, pp. 99-110, 2005.

[220] A. L. Goenaga, Y. Zhou, C. Legay et al., "Identification and characterization of tumor antigens by using antibody phage display and intrabody strategies," Molecular Immunology, vol. 44, no. 15, pp. 3777-3788, 2007.

[221] D. G. Menter, R. L. Schilsky, and R. N. DuBois, "Cyclooxygenase-2 and cancer treatment: understanding the risk should be worth the reward," Clinical Cancer Research, vol. 16, no. 5, pp. 1384-1390, 2010.

[222] R. N. DuBois, "New, long-term insights from the adenoma prevention with celecoxib trial on a promising but troubled class of drugs," Cancer Prevention Research, vol. 2, no. 4, pp. 285-287, 2009.

[223] A. J. Duffield-Lillico, J. O. Boyle, X. K. Zhou et al., "Levels of prostaglandin $\mathrm{E}$ metabolite and leukotriene $\mathrm{E}_{4}$ are increased in the urine of smokers: evidence that celecoxib shunts arachidonic acid into the 5-lipoxygenase pathway," Cancer Prevention Research, vol. 2, no. 4, pp. 322-329, 2009.

[224] C. A. C. Hyde and S. Missailidis, "Inhibition of arachidonic acid metabolism and its implication on cell proliferation and tumour-angiogenesis," International Immunopharmacology, vol. 9, no. 6, pp. 701-715, 2009.

[225] G. Coruzzi, N. Venturi, and S. Spaggiari, "Gastrointestinal safety of novel nonsteroidal antiinflammatory drugs: selective COX-2 inhibitors and beyond," Acta Biomedica de l'Ateneo Parmense, vol. 78, no. 2, pp. 96-110, 2007.

[226] L. Goossens, N. Pommery, and J. P. Hénichart, "COX2/5-LOX dual acting anti-inflammatory drugs in cancer chemotherapy," Current Topics in Medicinal Chemistry, vol. 7, no. 3, pp. 283-296, 2007.

[227] S. Leone, A. Ottani, and A. Bertolini, "Dual acting antiinflammatory drugs," Current Topics in Medicinal Chemistry, vol. 7, no. 3, pp. 265-275, 2007.

[228] M. Bayés and X. Rabasseda, "Gateways to clinical trials," Methods and Findings in Experimental and Clinical Pharmacology, vol. 30, no. 1, pp. 67-99, 2008.

[229] C. Ding and F. Cicuttini, "Licofelone merckle," IDrugs, vol. 6, no. 8, pp. 802-808, 2003.

[230] M. Moreau, S. Daminet, J. Martel-Pelletier, J. Fernandes, and J. P. Pelletier, "Superiority of the gastroduodenal safety profile of licofelone over rofecoxib, a COX-2 selective inhibitor, in dogs," Journal of Veterinary Pharmacology and Therapeutics, vol. 28, no. 1, pp. 81-86, 2005.

[231] P. Bias, A. Buchner, B. Klesser, and S. Laufer, "The gastrointestinal tolerability of the LOX/COX Inhibitor, licofelone, is similar to placebo and superior to naproxen therapy in healthy volunteers: results from a randomized, controlled trial," The American Journal of Gastroenterology, vol. 99, no. 4, pp. 611-618, 2004.

[232] J. P. Raynauld, J. Martel-Pelletier, P. Bias et al., "Protective effects of licofelone, a 5-lipoxygenase and cyclo-oxygenase inhibitor, versus naproxen on cartilage loss in knee osteoarthritis: a first multicentre clinical trial using quantitative MRI," Annals of the Rheumatic Diseases, vol. 68, no. 6, pp. 938-947, 2009.

[233] S. Sharma, J. Lee, J. Zhou, and V. E. Steele, "Chemopreventive efficacy and mechanism of licofelone in a mouse lung tumor model via aspiration," Cancer Prevention Research, vol. 4, no. 8, pp. 1233-1242, 2011.

[234] J. P. Iyer, P. K. Srivastava, R. Dev, S. G. Dastidar, and A. Ray, "Prostaglandin $\mathrm{E}_{2}$ synthase inhibition as a therapeutic target," Expert Opinion on Therapeutic Targets, vol. 13, no. 7, pp. 849-865, 2009.

[235] N. Baryawno, B. Sveinbjörnsson, S. Eksborg et al., "Tumorgrowth-promoting cyclooxygenase-2 prostaglandin $\mathrm{E}_{2}$ pathway provides medulloblastoma therapeutic targets," NeuroOncology, vol. 10, no. 5, pp. 661-674, 2008.

[236] M. Nakanishi, A. Menoret, T. Tanaka et al., "Selective PGE suppression inhibits colon carcinogenesis and modifies local mucosal immunity," Cancer Prevention Research, vol. 4, no. 8, pp. 1198-1208, 2011.

[237] M. Isono, T. Suzuki, K. Hosono et al., "Microsomal prostaglandin E synthase-1 enhances bone cancer growth and bone cancer-related pain behaviors in mice," Life Sciences, vol. 88, no. 15-16, pp. 693-700, 2011.

[238] R. L. Jones, M. A. Giembycz, and D. F. Woodward, "Prostanoid receptor antagonists: development strategies and therapeutic applications," British Journal of Pharmacology, vol. 158, no. 1, pp. 104-145, 2009.

[239] D. F. Legler, M. Bruckner, E. Uetz-von Allmen, and P. Krause, "Prostaglandin $\mathrm{E}_{2}$ at new glance: novel insights in functional diversity offer therapeutic chances," International Journal of Biochemistry and Cell Biology, vol. 42, no. 2, pp. 198-201, 2010.

[240] L. Yang, Y. Huang, R. Porta et al., "Host and direct antitumor effects and profound reduction in tumor metastasis with selective $\mathrm{EP}_{4}$ receptor antagonism," Cancer Research, vol. 66, no. 19, pp. 9665-9672, 2006.

[241] K. A. Maubach, R. J. Davis, D. E. Clark et al., "BGC201531, a novel, potent and selective prostanoid $\mathrm{EP}_{4}$ receptor antagonist: a putative new treatment for migraine headache," British Journal of Pharmacology, vol. 156, no. 2, pp. 316-327, 2009.

[242] D. Cox, M. Brennan, and N. Moran, "Integrins as therapeutic targets: lessons and opportunities," Nature Reviews Drug Discovery, vol. 9, no. 10, pp. 804-820, 2010.

[243] J. S. Desgrosellier and D. A. Cheresh, "Integrins in cancer: biological implications and therapeutic opportunities," Nature Reviews Cancer, vol. 10, no. 1, pp. 9-22, 2010.

[244] D. A. Reardon, B. Neyns, M. Weller, J. C. Tonn, L. B. Nabors, and R. Stupp, "Cilengitide: an RGD pentapeptide $\alpha_{\mathrm{V}} \beta_{3}$ and $\alpha_{\mathrm{V}} \beta_{5}$ integrin inhibitor in development for glioblastoma and other malignancies," Future Oncology, vol. 7, no. 3, pp. 339354, 2011. 
[245] R. Pytela, M. D. Pierschbacher, and E. Ruoslahti, "Identification and isolation of a $140 \mathrm{kd}$ cell surface glycoprotein with properties expected of a fibronectin receptor," Cell, vol. 40, no. 1, pp. 191-198, 1985.

[246] L. J. Gamble, A. V. Borovjagin, and Q. L. Matthews, "Role of RGD-containing ligands in targeting cellular integrins: applications for ovarian cancer virotherapy (Review)," Experimental and Therapeutic Medicine, vol. 1, no. 2, pp. 233-240, 2010.

[247] S. K. Akiyama, K. Olden, and M. Yamada, "Fibronectin and integrins in invasion and metastasis," Cancer and Metastasis Reviews, vol. 14, no. 3, pp. 173-189, 1995.

[248] O. W. Blaschuk and E. Devemy, "Cadherins as novel targets for anti-cancer therapy," European Journal of Pharmacology, vol. 625, no. 1-3, pp. 195-198, 2009.

[249] G. M. Beasley, J. C. Riboh, C. K. Augustine et al., "Prospective multicenter phase II trial of systemic ADH-1 in combination with melphalan via isolated limb infusion in patients with advanced extremity melanoma," Journal of Clinical Oncology, vol. 29, no. 9, pp. 1210-1215, 2011.

[250] G. M. Beasley, N. McMahon, G. Sanders et al., "A phase 1 study of systemic ADH-1 in combination with melphalan via isolated limb infusion in patients with locally advanced intransit malignant melanoma," Cancer, vol. 115, no. 20, pp. 4766-4774, 2009.

[251] M. Guarino, "Src signaling in cancer invasion," Journal of Cellular Physiology, vol. 223, no. 1, pp. 14-26, 2010.

[252] V. G. Brunton and M. C. Frame, "Src and focal adhesion kinase as therapeutic targets in cancer," Current Opinion in Pharmacology, vol. 8, no. 4, pp. 427-432, 2008.

[253] J. T. Parsons, J. Slack-Davis, R. Tilghman, and W. G. Roberts, "Focal adhesion kinase: targeting adhesion signaling pathways for therapeutic intervention," Clinical Cancer Research, vol. 14, no. 3, pp. 627-632, 2008.

[254] C. Walsh, I. Tanjoni, S. Uryu et al., "Oral delivery of PND-1186 FAK inhibitor decreases tumor growth and spontaneous breast to lung metastasis in pre-clinical models," Cancer Biology and Therapy, vol. 9, no. 10, pp. 778-790, 2010.

[255] I. Tanjoni, C. Walsh, S. Uryu et al., "PND-1186 FAK inhibitor selectively promotes tumor cell apoptosis in threedimensional environments," Cancer Biology and Therapy, vol. 9, no. 10, pp. 764-777, 2010.

[256] M. D. Schaller and S. M. Frisch, "PND-1186 FAK inhibitor selectively promotes tumor cell apoptosis in three-dimensional environments," Cancer Biology and Therapy, vol. 9, no. 10, pp. 791-793, 2010.

[257] A. Zhang, M. H. Wang, Z. Dong, and T. Yang, "Prostaglandin $\mathrm{E}_{2}$ is a potent inhibitor of epithelial-to- mesenchymal transition: interaction with hepatocyte growth factor," American Journal of Physiology-Renal Physiology, vol. 291, no. 6, pp. F1323-F1331, 2006.

[258] A. Zhang, Z. Dong, and T. Yang, "Prostaglandin $D_{2}$ inhibits TGF- $\beta_{1}$-induced epithelial-to-mesenchymal transition in MDCK cells," American Journal of Physiology — Renal Physiology, vol. 291, no. 6, pp. F1332-F1342, 2006.

[259] V. Konya, E. M. Sturm, P. Schratl et al., "Endotheliumderived prostaglandin $\mathrm{I}_{2}$ controls the migration of eosinophils," Journal of Allergy and Clinical Immunology, vol. 125 , no. 5, pp. 1105-1113, 2010. 

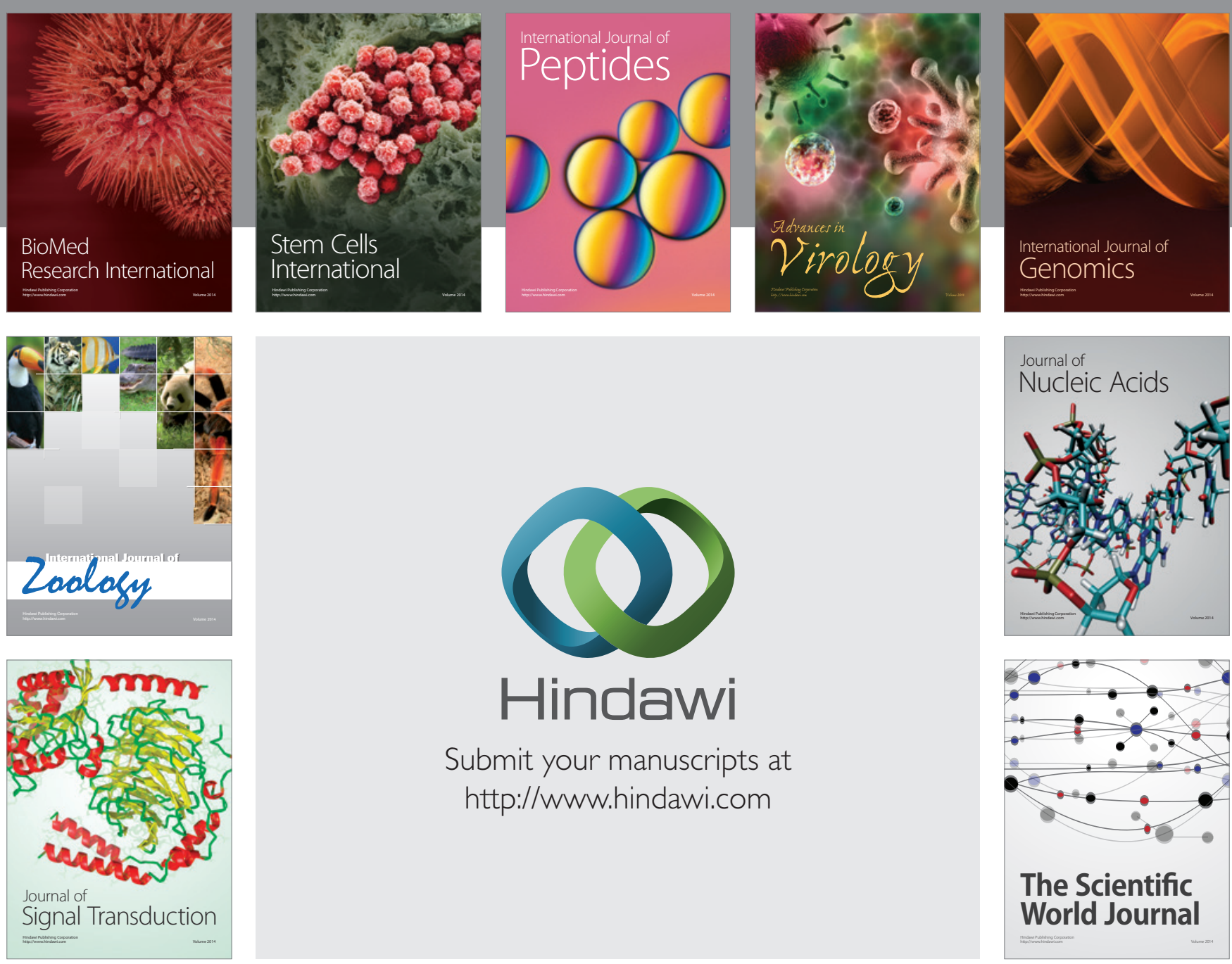

Submit your manuscripts at

http://www.hindawi.com
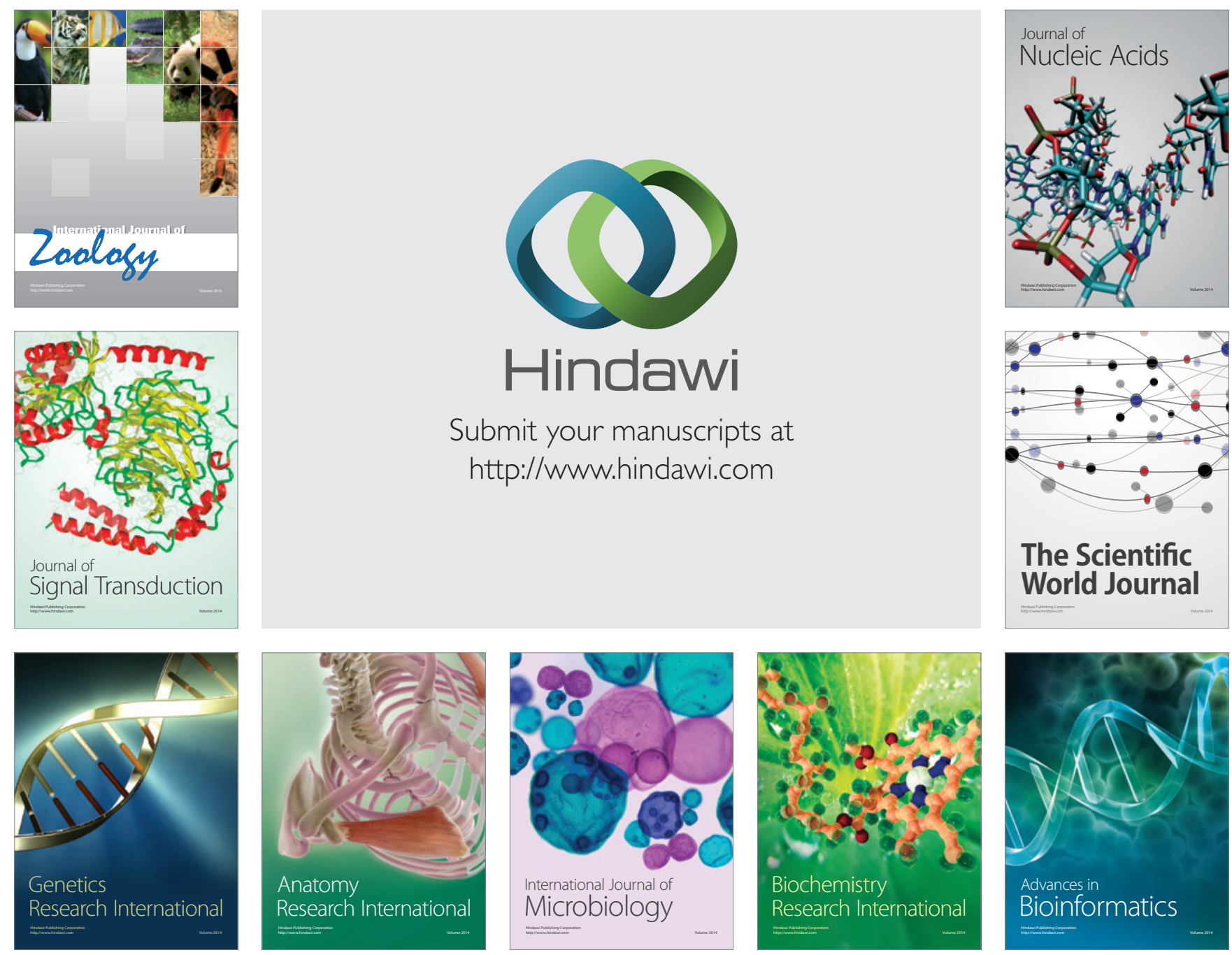

The Scientific World Journal
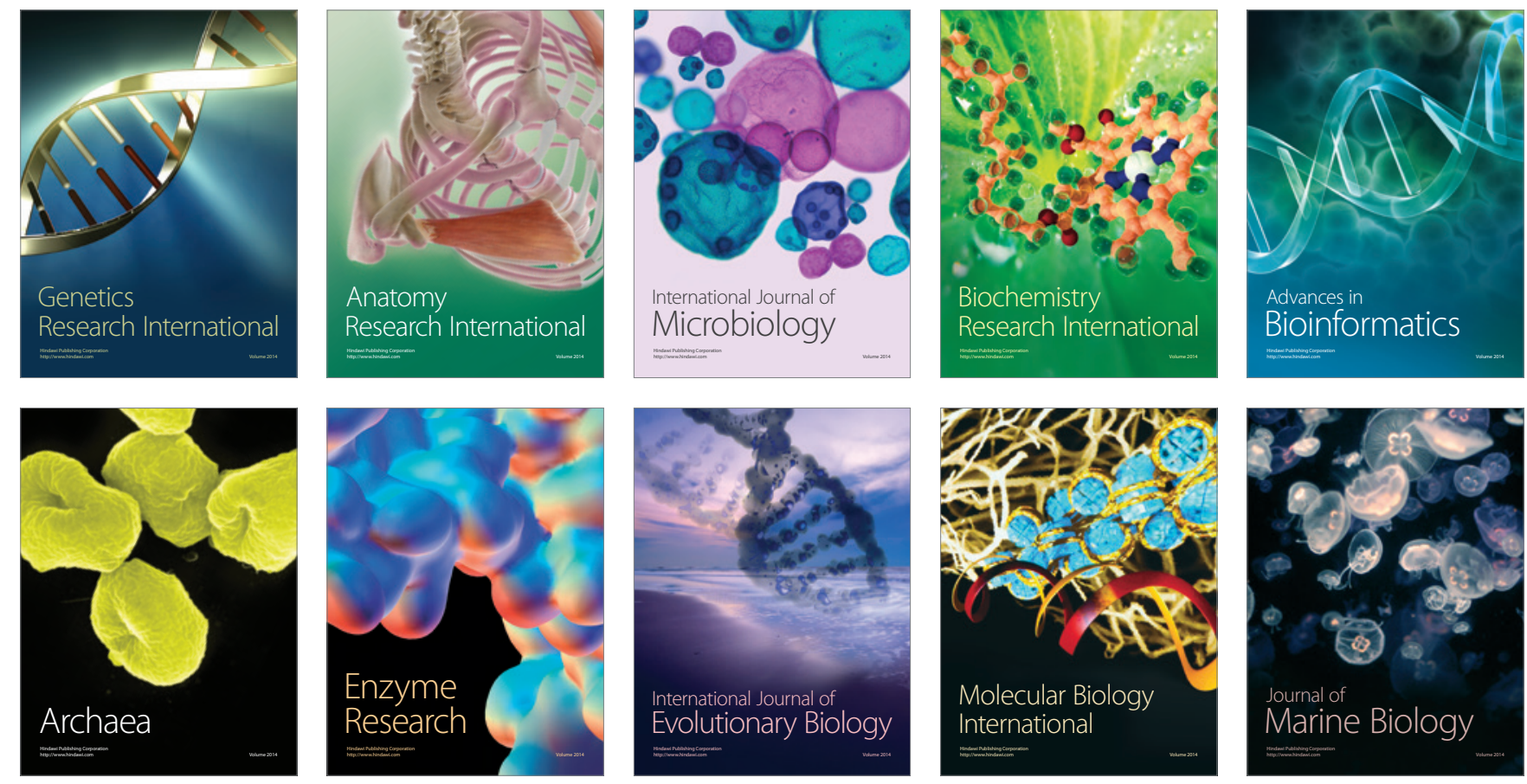